\title{
JUdiCIALIZAÇÃo da POLÍTICA E POLITIZAÇÃO DO DIREITO: A ROTA ESTRUTURANTE DA DEMOCRACIA PLURALISTA E UNIVERSALISTA ENQUANTO UM SISTEMA PÚBLICO DE DIREITO
}

\author{
[JURIDIFICATION OF POLITICS AND POLITICIZATION OF LAW: THE STRUCTURING ROUTE OF THE \\ PLURALIST AND UNIVERSALIST DEMOCRACY AS A PUBLIC SYSTEM OF LAW]
}

\author{
Leno Francisco Danner * \\ Fernando Danner ** \\ Universidade Federal de Rondônia, Brasil
}

\begin{abstract}
Resumo: O artigo discute as questões de judicialização da política e de politização do direito tendo como pano de fundo a consolidação institucional e social de uma perspectiva fascista caracterizada como personalismo jurídico-político antissistêmico, anti-institucional, antijurídico e infralegal, demarcada pela implosão do judiciário desde dentro através exatamente da politização do direito, com sua vinculação direta à guerra político-partidária fratricida no âmbito do sistema político. A partir disso, procura reconstruir os fundamentos normativo-
\end{abstract} institucional-procedimentais próprios à democracia pluralista e universalista constituída enquanto um sistema público de direito, quais sejam: a correlação originária e a emergência concomitante de direitos humanos e direito; a primazia ontogenética, a diferenciação, a autonomia, a autorreferencialidade e a sobreposição do direito em relação à política e à moral, com a subsidiariedade destas àquele; a separação, a autonomia, a autossubsistência e a sobreposição do judiciário em relação ao sistema político; a condição sistêmica, sistemática, processual, mediada, instancial, progressiva e publicizada do judiciário e do sistema político; o forte ideal sistêmico de institucionalidade, legalidade, tecnicalidade, formalidade e despersonalização; a postura axiológica imparcial, impessoal, neutra e
ABstract: The paper discusses the questions of judicialization of politics and politicization of law having as background the institutional and social consolidation of a fascist perspective characterized as anti-systemic, antiinstitutional, anti-juridical and infralegal juridical-political personalism, which is streamlined by the implosion of judiciary from inside to outside exactly by politicization of law, with its direct link to the fratricide political-partisan war in the sphere of the political system. From this starting point, we will reconstruct the normative-institutionalprocedural fundaments proper to the pluralist and universalist democracy constituted as a public system of law, which are: the original correlation and the concomitant emergence of human rights and law; the ontogenetic primacy, differentiation, autonomy, self-referentiality and overposition of law regarding to politics and moral, as well as the subsidiarity of politics and moral to law; the separation, autonomy, self-subsistence and overposition of judiciary in relation to political system; the systemic, systematic, procedural, mediated, instantial, progressive, neutral and apolitical-depoliticized condition of judiciary and political system; the strong systemic ideal of institutionality, legality, technicality, formality and depersonalization; the axiological posture of impartiality, impersonality, neutrality and apoliticity-depoliticization by judiciary and

* Doutor em Filosofia pela Pontificia Universidade Católica do Rio Grande do Sul (PUC_RS). Professor de teoria política contemporânea no Departamento de Filosofia e no Programa de PósGraduação em Filosofia da Universidade Federal de Rondônia. E-mail: leno danner@yahoo.com.br. **Doutor em Filosofia pela Pontificia Universidade Católica do Rio Grande do Sul PUCRS). Professor de ética e filosofia política no Departamento de Filosofia e no Programa de Pós-Graduação em Filosofia da Universidade Federal de Rondônia (UNIR). Email: fernando.danner@gmail.com 
apolítico-despolitizada por parte do judiciário e do sistema político. Estes fundamentos têm por meta a produção institucional autorreflexiva, autocontrolada e autocorretiva da universalidade na/como/pela legalidade e, nesse sentido, implicam na constituição de um Estado democrático de direito antifascista, antitotalitário, não-fundamentalista e antirracista que combate seja o personalismo jurídico-político antissistêmico, antiinstitucional, antijurídico e infralegal, seja a politização, a partidarização e a instrumentalização do direito, garantindo a centralidade dos direitos humanos, do pluralismo, do devido processo legal e do direito como princípio, procedimento, linguagem e símbolo definidor da própria democracia pluralista e universalista constituída como um sistema público de direito. Ora, reconstruir tais fundamentos é uma questão imperiosa para solidificarmos teórica e normativamente uma postura de enfrentamento e de desconstrução do fascismo hegemônico institucional e socialmente.

Palavras-Chave: Judicialização da política; Politização do direito; Democracia; Direito; Política; Moral political system. These fundaments have the goal of strengthening the self-reflexive, selfcontrolled and self-corrective institutional production of the universality in/as/by legality and, in this sense, they implicate in the constitution of an anti-fascist, anti-totalitarian, non-fundamentalist and anti-racist democratic rule of law which fights against both antisystemic, anti-institucional, anti-juridical and infralegal juridical-political personalism, as the politicization, partisanship and reification of law, ensuring the centrality of human rights, of pluralism, of legal process and of the law as defining principle, procedure, language and symbol of the own pluralist and universalist democracy constituted as a public system of law. Now, the reconstruction of these fundaments is a very urgent matter in order to solidify theoretically and normatively a perspective of facing and deconstruction of the fascism hegemonic institutionally and socially.

KEYWORDS: Juridification of politics; Politicization of law; Democracy; Law; Politics; Moral

\section{CONSIDERAÇÕES INICIAIS}

Por que o fascismo emergiu com tanta força em nossa democracia que, embora frágil e fortemente demarcada por perspectivas regressivas em termos institucionais, políticoculturais e socioeconômicos, tem conseguido evoluir em torno a uma constituição federal progressista e em termos de protagonismo de suas instituições públicas? Por outro lado, qual é o significado e quais são as bases estruturantes, os princípios fundacionais e a dinâmica constitutivo-legitimatória próprios a uma democracia pluralista e universalista constituída como um sistema público de direito direcionado à produção da universalidade na/como/pela legalidade? E, assim, qual é o sentido e quais são as implicações das questões ligadas à judicialização da política e à politização do direito em termos da efetividade teórico-prática do sistema público de direito democrático em sua intersecção, diferenciação, separação, autonomia e sobreposição de judiciário e sistema político (e, neste, de legislativo bicameral frente ao executivo), bem como no que se refere à primazia ontogenética, à separação, à diferenciação, à autonomia, à autossubsistência e à sobreposição do direito em relação à política e à moral? Neste artigo, queremos responder filosoficamente a estas questões a partir do argumento de que é exatamente o solapamento do sistema público de direito desde dentro, no contexto do judiciário, em termos de um personalismo jurídico-político antissistêmico, anti-institucional, antijurídico e infralegal, que corroeu (e que corrói, na medida em que ainda se mantém ativo) profundamente seja a primazia ontogenética, a separação, a diferenciação, a autonomia, a independência, a endogenia, a autorreferencialidade, a autossubsistência, a autossuficiência e a sobreposição do direito em relação à política e à moral (e a consequente subsidiariedade destas em relação àquele), seja, no mesmo diapasão, a separação, a autonomia, a integridade e a sobreposição do judiciário em relação ao sistema político, permitindo que o fascismo fosse assumido e fomentado primeiramente desde dentro do judiciário para fora, e, então, em segundo lugar, em termos de luta político-partidária fratricida no contexto do sistema político, ramificando-se, finalmente, à sociedade civil sob a forma de criação e de estímulo permanentes de uma massa-milícia digital-social de aclamação garantidora da implosão institucional e da deslegitimação do direito em particular e do 
sistema público de direito de um modo mais geral.

Para nós, por conseguinte, o fenômeno-fato-movimento fundador e dinamizador da versão contemporânea do fascismo brasileiro, isto é, fascismo como personalismo jurídico-político antissistêmico, anti-institucional, antijurídico e infralegal, consiste na politização, na partidarização e na instrumentalização do direito realizada por setores do judiciário em profunda conexão com a guerra político-partidária fratricida que, a partir da segunda década do século XXI para cá, tem intensificado tanto o enfraquecimento e a subversão institucionais quanto a regressão jurídico-política totalizante que afetam nossa sociedade brasileira. De fato, a politização e a partidarização do direito significam que setores do judiciário se utilizam abertamente - e em concerto com lideranças e partidos políticos específicos - de lawfare institucional, de polícia de Estado e de Estado de exceção (ou seja, de subversão do direito) para produzir transformação política, tomando partido nessa guerra políticopartidária fratricida, não só desestabilizando a balança de poder própria ao sistema político (a qual é sustentada por um judiciário independente e íntegro e pela concorrência multipartidária dentro das regras, dos procedimentos, dos símbolos e dos valores do Estado democrático de direito), mas também solapando o próprio Estado democrático de direito exatamente para garantir essa guerra políticopartidária fratricida. Com isso, o direito deixa de ser a base fundante, estruturadora e legitimadora da política e da moral para se tornar, em verdade, política e moral, de modo que, nesse caso, a democracia perde completamente sua base, seu princípio, seu procedimento, sua linguagem e seu símbolo nucleares. Como consequência, o judiciário, na medida em que toma partido, na medida em que se dinamiza por ativismo político, implode-se desde dentro em termos de sua condição basilar no que se refere às atividades de controle de constitucionalidade e de responsabilização jurídico-social, instaurando uma situação consolidada de insegurança jurídica e de quebra de isonomia, simetria e horizontalidade jurídicas que dão o golpe de morte na limitação institucional seja ao sistema político (e por parte deste), seja à sociedade civil (e por parte desta), reduzindo a nada as mediações jurídicas estruturantes e o devido processo legal. Ora, é nesse momento em que o direito deixa de ser o princípio, o procedimento, a linguagem e o símbolo estruturantes da democracia, dando lugar à política e à moral, e em que o judiciário implode-se desde dentro em sua condição de instituição fundamental de validação da democracia como um todo, é nesse momento em que perspectivas antissistêmicas, anti-institucionais, antijurídicas e infralegais saem à luz do dia com toda a pujança em sua cruzada contra o Estado democrático de direito, ganhando hegemonia institucional e social concomitantemente e, de sua parte, engolfando o próprio direito e o próprio judiciário nessa sua postura de destruição institucional e de regressão política totalizante (setores do judiciário que, paradoxalmente, produziram e fomentaram esse mesmo fascismo e que agora são suas primeiras vítimas).

Nesse sentido, a partir deste diagnóstico, objetivamos reconstruir os fundamentos normativo-institucionais-procedimentais da democracia pluralista e universalista constituída como um sistema público de direito direcionado à produção autorreflexiva, autocontrolada e autocorretiva da universalidade na/como/pela legalidade, em sua condição antifascista, antitotalitária, nãofundamentalista e antirracista. Entre estes fundamentos, procuraremos ressaltar: (a) a correlação originária e o aparecimento concomitante de direitos humanos e direito, de direito como tendo por base exclusiva, suficiente e necessária aos direitos humanos e estes materializando-se (somente, primordialmente) no/como/pelo direito; (b) a consequente primazia ontogenética, separação, diferenciação, autonomia, independência, endogenia, autorreferencialidade, autossubsistência, autossuficiência e sobreposição do direito em relação à política e à moral, com a subsidiariedade destas àquele, o que implica, primeiramente, que a democracia é direito e só depois e como condição para tudo o mais, política e moral, bem como de que a política e a moral precisam fundar-se plenamente na universalidade dos direitos humanos $\mathrm{e}$ traduzir-se completamente no procedimentalismo, na principialidade, na simbologia e na linguagem do direito positivo, tanto na sua esfera privado-comunitária quanto em sua vinculação público-institucional, se quiserem legitimidade e validade democráticas; (c) a separação, a diferenciação, a autonomia e a sobreposição do judiciário em relação ao sistema político (e, neste, do legislativo bicameral em relação ao executivo), com o compartilhamento de tarefas entre judiciário e sistema político no que se refere à materialização dos direitos humanos e à proteção do pluralismo-diversidade (objetivo fundacional das instituições públicas), o judiciário assumindo as tarefas de controle de constitucionalidade e responsabilização jurídico-social e o sistema político tendo por meta a produção de políticas públicas, de previsão constitucional e de principialidade jurídica (sempre sob supervisão do judiciário - judicialização da política); (d) a perspectiva sistêmica, sistemática, processual, mediada, instancial, progressiva e publicizada, tanto por parte do judiciário quanto por parte do sistema político, relativamente à 
produção da objetividade normativo-jurídico-política; (e) uma atuação sistêmica, mais uma vez seja pelo judiciário, seja pelo sistema político, altamente institucionalista, legalista, tecnicista, formalista e despersonalizada; e (f) uma postura axiológica imparcial, impessoal, neutra e apolítico-despolitizada, primeiramente por parte do judiciário, bem como, em segundo lugar, por parte do próprio sistema político. Esses seis núcleos normativo-institucionais-procedimentais estruturantes dos sistemas sociais direito e política têm por meta erradicar o personalismo jurídico-político antissistêmico, antiinstitucional, antijurídico e infralegal desde dentro do judiciário e, a partir daqui e como condição para tudo o mais, seja do sistema político, seja da sociedade civil, evitando-se, ainda e por consequência, a politização-partidarização do direito e fomentando-se uma postura institucional e social antifascista, antitotalitária, não-fundamentalista e antirracista calcada na universalidade dos direitos humanos, no pluralismo-diversidade, no Estado democrático de direito, no próprio direito, em suas mediações estruturantes (garantidoras de isonomia, segurança, horizontalidade e simetria jurídicas) e no devido processo legal público-publicizado.

\section{A CO-ORIGINARIEDADE DE DIREITOS HUMANOS E DIREITO, A PRECEDÊNCIA ONTOGENÉTICA DO DIREITO EM RELAÇÃO À POLÍTICA E À MORAL E A SUBSIDIARIEDADE DA POLÍTICA E DA MORAL AO DIREITO: OU SOBRE A BASE ESTRUTURANTE DA DEMOCRACIA}

A democracia pluralista e universalista constituída enquanto um sistema público de direito ou como um Estado democrático de direito - consiste em uma perspectiva societal-institucionalnormativa demarcada pela imbricação originária e pela emergência concomitante de pluralismodiversidade, direitos humanos e Estado democrático de direito, sendo centralizada e dinamizada como uma (e por uma) base estruturante e gerenciadora com caráter sistêmico, sistemático, processual, mediado, instancial, progressivo e publicizado altamente institucionalista, legalista, tecnicista, formalista e despersonalizada, a qual tem por meta a produção autorreflexiva, autocontrolada e autocorretiva da objetividade normativo-jurídico-política, isto é, a produção da universalidade na/como/pela legalidade como o objetivo constitutivo e definidor dessa e por essa democracia pluralista e universalista através de seu sistema público de direito. É importante, para começo de conversa, contrapormos a democracia pluralista e universalista constituída enquanto um sistema público de direito ao seu inimigo mais fundamental, a saber, o fascismo-totalitarismo, calcado no racismo estrutural, no fundamentalismo religioso, no etnocentrismo cultural e no instrumentalismo econômico. É contra ele que essa mesma democracia se estrutura e ganha todo o seu sentido, ao ponto de podermos definir essa noção de democracia acima explicitada enquanto uma condição societalinstitucional-normativa antifascista, antitotalitária, não-fundamentalista e antirracista fundada no pluralismo-diversidade-alteridade-diferença, na universalidade dos direitos humanos e no sistema público de direito, destinada à sua (do pluralismo e dos direitos humanos por meio do Estado democrático de direito) proteção e realização e orientada à desconstrução permanente do fascismo, do totalitarismo, do racismo, do fundamentalismo, do etnocentrismo e do instrumentalismo econômico através da atuação incisiva das instituições públicas e, em especial, em termos do compartilhamento de tarefas entre o judiciário, o qual assume o trabalho de controle de constitucionalidade e de responsabilização jurídico-social, e o sistema político, o qual tem por meta a produção de políticas públicas, de previsão constitucional e de principialidade jurídica, ambos atuando de modo contramajoritário (posto que fundados na universalidade dos direitos humanos, na proteção e no fomento do pluralismo, traduzidos no procedimentalismo, na principialidade, na simbologia e na linguagem do direito positivo e, finalmente, manifestados objetivamente apenas por meio do devido processo legal, inclusive em termos de imparcialidade, impessoalidade, neutralidade e apoliticidadedespolitização metodológico-procedimental-axiológicas).

Com efeito, o fascismo-totalitarismo, desde sua base constitutiva e dinamizadora, o racismo estrutural, o fundamentalismo religioso, o etnocentrismo cultural e o instrumentalismo econômico, está determinado seja por uma perspectiva personalista, voluntarista, espontaneísta, vocacionada, missionária e messiânica totalizante, massificadora, unidimensional e regressiva e por uma consequente postura antissistêmica, anti-institucional, antijurídica e infralegal, seja por um núcleo normativo pré-jurídico com caráter essencialista e naturalizado e levando ao dualismo-maniqueísmo político-moral, seja, finalmente, pela guerra de exclusão recíproca, pela negação do reconhecimento da alteridade e da universalidade dos direitos, pela destruição das mediações jurídicas estruturantes e, 
então, pela imposição direta, imediada e imediata da vontade do líder-partido-seita. No fascismo, esse mesmo líder-partido-seita tem um acesso direto à verdade do mundo, a qual é anterior à política portanto, apolítica-despolitizada, com caráter biológico e/ou religioso "puro" - e também anterior e sobreposta ao direito - portanto, nesse caso, o direito sendo compreendido pelo modelo fascista seja como uma forma de deturpação da verdade primigênia e de desvalorização do poder original nos quais o líder-partido-seita se embasa e busca reproduzir institucional e socialmente, seja como uma forma de contenção da atuação missionária e messiânica assumida por esse mesmo fascismo e que lhe é exigida por essa verdade pré-jurídica e pré-política, de modo que o direito (como Estado democrático de direito, como constituição política e direito positivo, como judiciário, como devido processo legal, como mediações jurídicas estruturantes, como separação, diferenciação e sobreposição entre poderes), aqui, coloca-se como o entrave básico a ser destruído, colonizado, politizado e instrumentalizado pelo fascismo (cf.: Habermas, 2012a; 2003a; 2002a; Honneth, 2007a; Honneth, 2007b; Rancière, 2014; Souza, 2012). Ora, o líder-partido-seita fascista vê direta e imediatamente essa verdade do mundo, enquanto dualismo-maniqueísmo moral e, assim, como guerra de exclusão recíproca entre posições antagônicas inconciliáveis e, ao vê-la diretamente, ao acessá-la imediatamente, (a) não precisa de mediações institucionais, seja de cunho político, seja de cunho jurídico, para compreendê-la; (b) assume o compromisso vocacionado de aplicá-la à pluralidade de modo direto, imediado e imediato, sem qualquer mediação, sequencialidade, progressividade, processualidade; e, finalmente, (c) necessita, para essa guerra de exclusão recíproca, de uma massa-milícia digital-social de aclamação como mera extensão corporal desse líder-partido-seita-cabeça, direcionada à destruição dos outros e, por conseguinte, à autodestruição de si. No fascismo, desde essa perspectiva do racismo estrutural, do fundamentalismo religioso e do dualismo-maniqueísmo moral, nós temos: (a) uma personalização do poder, centralizado, monopolizado e manifestado por esse líder-partido-seita, o qual se sobrepõe às próprias instituições, como em uma versão contemporânea barata, mas obviamente perigosa, de "O Estado/poder/direito/verdade sou eu"; (b) a produção e o estímulo permanente de uma massa-milícia digital-social de aclamação que, como mera extensão corporal dessa cabeça constituída pelo líderpartido-seita, reproduz no âmbito da sociedade civil (e direcionada à implosão desde fora do sistema público de direito) a perspectiva antissistêmica, anti-institucional, antijurídica e infralegal assumida por aquele no contexto interno ao judiciário e ao sistema político (nesse caso, implosão fascista do sistema público de direito desde dentro); (c) a negação da universalidade dos direitos humanos, a afirmação do pluralismo-diversidade como condição superficial, e não fundacional, a minimização ou mesmo a destruição das mediações jurídico-políticas, a deslegitimação, o travamento e a imobilização dos processos de reconhecimento, inclusão e participação democráticos e, então, por meio da imposição institucional e social do dualismo-maniqueísmo moral, tanto o conflito aberto contra as instituições e o solapamento da separação, da diferenciação e da sobreposição entre poderes quanto a normalização de uma postura concomitante de lawfare institucional, polícia de Estado e Estado de exceção e de guerra de exclusão recíproca contra adversários (cf.: Honneth, 2003; Catroga, 2006).

A lógica estruturante do fascismo consiste na dinâmica moral-direito-moral, moral-políticamoral e moral-cultura-moral ou, em outros termos, na dinâmica biologia-moral-biologia, biologiapolítica-biologia, biologia-direito-biologia e biologia-cultura-biologia. É nessa lógica que o racismo estrutural, o fundamentalismo religioso, o etnocentrismo cultural e o instrumentalismo econômico se embasam e se dinamizam. Na compreensão fascista, essa lógica implica em que a política, o direito e a cultura sejam uma consequência de uma perspectiva pré-política, pré-jurídica, pré-cultural e ahistórica que é dada seja por uma suposta estrutura genético-fisiológica racializada (negro-indígena versus branco) e dualista (binarismo de gênero e heterossexualidade compulsória), demarcada, portanto, pela correlação e pela intersecção de raça, sexo e gênero (e, a partir desta intersecção, levando diretamente à estratificação e à mobilidade sociais, agora naturalizadas e, portanto, despolitizadas), seja por uma escatologia e por uma teodiceia religiosas que, mais uma vez utilizandose dessa noção caricata de biologia, sustentam uma ordem do mundo e do homem anterior à história e com caráter essencialista e naturalizado, verticalizado, massificador, unidimensional e totalizante, destinada a reduzir as diferenças a uma unidade, integração e ordem de família, como uma grande família indivisa, indiferenciada, unificada e de forte hierarquia, imobilismo e autoridade internas (Cf.: Fernandes, 2008; Nascimento, 2016; Souza, 2012; Leal, 2012; Habermas, 2002b). Inclusive, no caso da escatologia e da teodiceia religiosas, mais uma vez o dualismo-maniqué́smo entre eleitos e condenados orienta direta e pungentemente a essa guerra de exclusão recíproca, posto que, da mesma forma como uma interpretação simplista e simplificada da biologia em termos de racismo estrutural, de binarismo de gênero e de heterossexualidade compulsória cria os sujeitos pré-civilizados, antinaturais, anormais e decaídos que destroem essa ordem e essa estratificação naturais normalizadas, 
agora no âmbito do fundamentalismo religioso temos exatamente esses grupos-sujeitos de antemão condenados que, enquanto subsistirem, colocarão em risco a integridade e a pureza do lado bom da força. Note-se que, da mesma forma como raças inferiores e sujeitos-grupos anormais e antinaturais degenerados não podem ser integrados institucional e socialmente sem destruir a normalidade racial, étnica, de sexo e de gênero dada pela biologia, também não se pode, no caso do fundamentalismo, conciliar e integrar o lado mau da força sem que isso implique na própria destruição do seu reverso, da sua cura, o lado bom da força. Por isso, em ambos os casos, é a guerra de exclusão recíproca - porque, em primeiro lugar, no dualismo-maniqueísmo moral fascista os contrários se excluem fundacionalmente, não podendo ser integrados e harmonizados - a regra estruturante, justificadora e dinamizadora do fascismo, e ela implica na recusa das mediações jurídico-políticas institucionalizadas e estruturantes, na deslegitimação da universalidade dos direitos e das garantias fundamentais e no solapamento da centralidade do sistema público de direito, do devido processo legal e da separação e da sobreposição entre poderes. Na lógica fascista, por conseguinte, o direito, a política e a cultura, assim como as instituições públicas democráticas, são subsidiários à moral totalizante, unidimensional e massificadora, a qual, por ser essencialista e naturalizada, por possuir uma condição pré-política, préjurídica, pré-cultural e a-histórica, naturaliza e despolitiza as diferenças e, de modo fundacional, as simplifica e as homogeneiza, dando um sentido religioso-biológico à antropologia, concebendo as diferenças como mera superficialidade, e não como condição fundacional, e produzindo minorias político-culturais como seu (do fascismo) substrato e consequência. No mesmo diapasão, a moral não apenas determina a subsidiariedade da política e do direito a ela, mas também impele a uma cruzada antissistêmica que tem por objetivo colonizar o sistema político e, desde ele, instrumentalizar o sistema público de direito de um modo geral e o direito em particular, partidarizando-os e utilizando-se deles como ferramentas dessa guerra de exclusão recíproca que transita das instituições para a sociedade civil e desta para aquelas, travando, imobilizando, invisibilizando e, ao fim e ao cabo, deslegitimando os processos de reconhecimento, inclusão, integração e participação próprios a sociedades pluralistas, diferenciadas, heterogêneas e complexas (cf.: Habermas, 2003b; Habermas, 2002b; Hunt, 2009). Nesse caso, o sistema público de direito e, nele, as instituições públicas, em particular o Estado (em termos de executivo-legislativo e de instituições públicas subsidiárias, como os ministérios) e o judiciário, são assimilados a essa lógica fascista em que a moral pré-política, préjurídica, pré-cultural e a-histórica e concebida em termos essencialistas e naturalizados, assumindo um caráter totalizante, unidimensional e massificador, subsume o direito e a política e, assim, ao colonizálos, ao ensacá-los desde essa perspectiva naturalizada e apolítica-despolitizada, simplesmente destrói qualquer diferença, separação e sobreposição entre poderes, direcionando-os ao travamento, à imobilização e à deslegitimação do pluralismo-diversidade, da universalidade dos direitos humanos e do sistema público de direito.

Nessa lógica fascista, por conseguinte, temos o apagamento da diferenciação, da separação e da autonomia do direito e da política em relação à moral, de modo que tanto o direito quanto a política se tornam mera extensão dela, reproduzindo-a em seus códigos e em suas práticas institucionais e, assim, militando em favor dela, impondo-a a uma coletividade plural e, mais ainda, levando as próprias instituições à produção, à legitimação e à reprodução de minorias político-culturais enquanto chagas normativas e perspectivas axiológicas antinaturais e anormais que justificam o fascismo em sua cruzada salvífica e vocacionada contra o sistema público de direito democrático e, desde ele, contra a universalidade dos direitos humanos e contra a centralidade do pluralismo-diversidade (e, aliás, justificam o fascismo em sua subversão, deturpação e degeneração do sistema público de direito e das instituições, procedimentos e valores públicos). Ao contrário dessa lógica, a democracia pluralista e universalista constituída enquanto um sistema público de direito parte ab initio da atribuição universalizada, a todos e a cada um, de direitos e de garantias fundamentais e de segurança, isonomia, simetria e horizontalidade jurídicas em caráter incondicional e irrestrito, inultrapassável e inviolável (ou seja, todos e cada um, inclusive os sujeitos-grupos fascistas, são, antes de tudo e como condição para tudo o mais, sujeitos de direito e, assim, sujeitos a direitos). Note-se, portanto, que a base estruturante para a compreensão da democracia pluralista e universalista consiste no fato de que somos, de modo primigênio, sujeitos de direito e sujeitos a direitos - e é importante ressaltarmos, como o faremos ao longo do texto, que essa condição primigênia de todos e de cada um dos sujeitos sociopolíticos enquanto sujeitos de e a direitos, na/como/pela democracia, pode ser verificada tanto no nível histórico-político quanto, para nosso caso nesse artigo, no âmbito metanormativo. Nesse sentido, é importante percebermos que, na gênese da democracia pluralista e universalista constituída enquanto um sistema público de direito, está exatamente essa percepção de que somos, mais uma vez antes de tudo e como condição para tudo o mais, sujeitos jurídicos ou sujeitos de direito e, então, sujeitos a 
direito, independentemente de nossas posições político-morais e de modo anterior a nossa contextualização histórico-político-cultural-econômica (tanto em termos metanormativos quanto no aspecto histórico-político, frise-se mais uma vez). Isso significa, conforme queremos expressar, a cooriginariedade de direitos humanos e de direito, de direitos humanos no/como/pelo direito e em termos de sua materialização sob a forma de direitos e de garantias fundamentais e de segurança, isonomia, simetria, horizontalidade e mediações jurídicas estruturantes, bem como da existência, da legitimidade e da centralidade do direito apenas através de sua fundação exclusiva, suficiente e necessária na universalidade dos direitos humanos. A democracia pluralista e universalista constituída enquanto um sistema público de direito é caracterizada, constituída, dinamizada e legitimada, em seu nível fundacional, pelo fato de que a diferença e a pluralidade estão ensacadas na universalidade dos direitos humanos manifestada como um sistema público de direito em sentido amplo, isto é, a constituição política e o direito positivo, o judiciário, o devido processo legal, as mediações jurídicas estruturantes e, então, a separação, a diferenciação e a sobreposição entre poderes.

A co-originariedade de direitos humanos e direito é o núcleo central da democracia, sem o qual ela não existiria e sem o qual não teria sentido a ideia de pluralismo-diversidade, de direitos e de garantias fundamentais e de Estado democrático de direito. Por isso mesmo, no que diz respeito tanto ao nível histórico-político quanto ao nível metanormativo, a democracia é direito, e só depois é política e moral; os direitos humanos são direito, e só depois política e moral; e, finalmente, as instituições públicas são direito, e só depois política e moral. Aparece, assim, a lógica estruturante da democracia enquanto sendo marcada pela dinâmica direito-moral-direito, direito-política-direito e direito-culturadireito, ou seja, e é isso que queremos desenvolver a partir de agora, o fato de que o direito, por causa de sua fundação exclusiva, suficiente e necessária na universalidade dos direitos humanos, é ontogeneticamente primário, diferenciado, separado, autônomo, independente, endógeno, autorreferencial, autossubsistente, autossuficiente e sobreposto à política e à moral, as quais são subsidiárias a ele, uma consequência dele. $\mathrm{Na}$ democracia pluralista e universalista constituída enquanto um sistema público de direito e através dele demarcada pela produção da universalidade na/como/pela legalidade, a política e a moral somente são legítimas se fundarem-se incondicionalmente na universalidade dos direitos humanos e se traduzirem-se completamente no procedimentalismo, na principialidade, na simbologia e na linguagem do direito positivo. Por causa da correlação e da emergência concomitante de direitos humanos e direito, ocorre uma separação estrita e uma diferenciação aguda entre direito, política e moral, a qual não pode ser desfeita democraticamente, institucionalmente, o que significa não só que uma democracia é direito antes de tudo e como condição para tudo o mais, e só depois é política e moral, mas também que seu sistema público de direito e suas instituições, dinâmicas, princípios e processos correlatos, como é o caso do judiciário e do sistema político, a separação e a sobreposição entre poderes e o devido processo legal, são direito, e não política e nem moral, bastando-lhes a correlação de direitos humanos e direito, sem qualquer necessidade de perspectivas pré-jurídicas garantidoras da objetividade e da legitimidade institucionais, inclusive de sua cogência social.

Ademais, na medida em que está fundado de modo exclusivo, suficiente e necessário na universalidade dos direitos humanos, o direito não possui nenhuma base pré-jurídica, já que há essa concomitância relativamente aos direitos humanos, e, portanto, também não precisa da política e da moral para sua fundamentação, sua constituição e sua dinamização teórico-práticas. Isso significa duas coisas, a saber: primeiramente, o direito é uma esfera conjuntural e sistêmica completa, autorreferencial e autossubsistente, basicamente diferenciada em relação à política e à moral; e, em segundo lugar, enquanto estrutura sistêmica, base normativa e procedimentalismo, principialidade, simbologia e linguagem lógico-técnica, formalista-despersonalizada e apolítico-despolitizada, bastalhe a universalidade dos direitos humanos e sua ramificação na constituição política e no direito positivo, no devido processo legal, na separação e na sobreposição entre os poderes e na centralidade do judiciário como a pedra angular da democracia, em sua atuação contramajoritária em termos de realização de suas tarefas de controle de constitucionalidade e de responsabilização jurídico-social. $\mathrm{O}$ direito é autônomo, independente, endógeno, autossubsistente, autorreferencial e sobreposto à política e à moral, somente podendo ser enquadrado, assumido e reflexivizado desde dentro do próprio direito e através da tradução ao direito, mas a política e a moral não são autorreferenciais e nem autossubsistentes, não possuindo qualquer perspectiva endógena e autônoma à correlação originária de direitos humanos e direito. Isso significa que a política e a moral, caso quiserem ser válidas a uma democracia, em uma democracia, precisam fundar-se de modo inultrapassável e incondicional na universalidade dos direitos humanos e traduzir-se completamente no procedimentalismo, na principialidade, na simbologia e na linguagem do direito positivo, podendo ser enquadradas, 
reflexivizadas, corrigidas e reorientadas com base no direito e em termos do protagonismo do sistema público de direito. $\mathrm{O}$ direito democrático, por causa de sua fundação na universalidade dos direitos humanos, não é política e nem moral, mas a política e a moral que possam ser chamadas de democráticas somente são possíveis pelo direito, no direito e como direito, isto é, repetimos mais uma vez, através de sua fundação na universalidade dos direitos humanos e de sua tradução ao procedimentalismo, à principialidade, à simbologia e à linguagem do direito positivo. Ademais, como estamos falando, o direito democrático nunca pode ser política e nem moral, nunca pode sofrer intervenção, colonização e instrumentalização da política e da moral, nunca pode ser complementado por elas, uma vez que lhe basta sua co-originariedade e sua relação de concomitância com os direitos humanos - os direitos humanos e sob a forma do sistema público de direito, do devido processo legal, das mediações jurídicas estruturantes, da linguagem, do procedimentalismo, da principialidade e da simbologia do direito positivo e da centralidade do judiciário são as únicas bases desde as quais a democracia é instituída, reflexivizada, corrigida e implantada, incluindo-se o próprio direito. Ao contrário mais uma vez, a política e moral são incompletas e deficitárias sempre que estão desligadas dos direitos humanos e do direito e, nesse sentido, em uma democracia a correlação originária de direitos humanos e direito e a precedência ontogenética do direito em relação à política e à moral implicam em que estas, enquanto subsidiárias daqueles, tenham inevitavelmente de ser enquadradas, reflexivizadas, corrigidas, orientadas e geridas pelo direito, não havendo nenhuma outra opção de legitimidade democrática que não o direito e o sistema público de direito, fundados exclusiva, necessária e suficientemente na universalidade dos direitos humanos (cf:: Habermas, 2003b; Habermas, 2012b).

Note-se que esta é a base fundacional e o núcleo normativo orientador de uma democracia pluralista e universalista constituída enquanto um sistema público de direito com caráter antifascista, antitotalitário, não-fundamentalista e antirracista, sem o qual, repetimos mais uma vez, não haveria democracia, mas fascismo, totalitarismo, racismo e fundamentalismo. A correlação originária entre direitos humanos e direito (o fato de que a universalidade dos direitos humanos se dá no direito e de que o direito é manifestação objetiva dos direitos humanos, não só estando baseado neles, mas também materializando-os em termos do sistema público de direito de um modo geral e da constituição política e do direito positivo em particular) coloca-se como o eixo estrutural, fundador e dinamizador dessa mesma democracia e ela implica, em primeira mão, (a) na precedência e na primariedade ontogenéticas, na separação, na diferenciação, na autonomia, na independência, na endogenia, na autorreferencialidade, na autossubsistência, na autossuficiência e na sobreposição do direito em relação à política e à moral; (b) na subsidiariedade e na consequencialidade da política e da moral frente ao direito; (c) na necessidade de fundação plena da política e da moral nos direitos humanos e de sua (da política e da moral) tradução completa ao procedimentalismo, à principialidade, à simbologia e à linguagem do direito positivo; (d) na legitimidade plena do enquadramento, da reflexivização, da correção e da orientação da política e da moral pelo direito; e (e) na ilegitimidade do enquadramento, reflexivização, correção, orientação e mesmo substituição do direito pela política e pela moral. O direito, como dissemos, é um sistema completo e autoestruturado que, fundado de modo exclusivo, suficiente e necessário na universalidade dos direitos humanos, forma um conjunto autorreferencial, uma base normativa autossubsistente e autossustentada e se ramifica em instituições, procedimentalismo, principialidade, simbologia e linguagem lógico-técnicos, formalistadespersonalizados e apolítico-despolitizados com caráter objetivo e endógeno. Ao contrário, a política e a moral não são sistemas conjunturais autoestruturados, autossubsistentes e autossuficientes, capazes de produzir direito fora do próprio direito, desde outra base normativa (a raça, a etnia, o sexo-gênero, a escatologia religiosa etc.) que não os direitos humanos e através de outros procedimentos que não a tradução completa da política e da moral ao procedimentalismo, à principialidade, à simbologia e à linguagem do direito positivo, a utilização do devido processo legal como o único instrumento democrático produtor de objetividade normativo-jurídico-política, a longa tramitação instancial hierárquica em termos de revisão, correção e confirmação de sentença entre as - e pelas - câmaras de revisão, com a formação concomitante de jurisprudência objetiva, similaridade decisória e previsibilidade de aplicação da norma e, finalmente, a separação e a sobreposição entre poderes (o judiciário sobre o sistema político, o legislativo sobre o executivo).

$\mathrm{O}$ direito, na medida em que está fundado de modo exclusivo, suficiente e necessário na universalidade dos direitos humanos, tornando-se, em verdade, sua materialização objetiva e ramificação abrangente em um sistema público de direito, assume precedência ontogenética que lhe permite fundar política e moral, o que também significa que, na democracia pluralista e universalista constituída enquanto um sistema público de direito, a fundação e a dinamização da política e da moral, 
tanto no âmbito da sociedade civil quanto na esfera público-institucional, se dá a partir do direito. Como dissemos, o contrário não é verdadeiro: as posições político-morais existentes em uma democracia não se fundam de modo primigênio na universalidade dos direitos humanos, mas em perspectivas normativas abrangentes com caráter pré-jurídico que, desreguladas, podem pôr em perigo a efetividade dos direitos humanos e sua universalidade, assim como a consequente legitimidade e estabilidade do sistema público de direito de um modo geral e o purismo lógico-técnico, formalistadespersonalizado e apolítico-despolitizado do direito em particular. Por isso que dissemos, acima, que a política e a moral são incompletas em uma democracia, necessitando do embasamento, da reflexivização, da correção e da orientação dos direitos humanos e do direito. É nesse sentido que a precedência ontogenética do direito em relação à política e à moral, sua endogenia, sua autonomia, sua independência, sua separação, sua diferenciação, sua autossubsistência, sua autorreferencialidade e sua autossuficiência frente à política e à moral, bem como sua sobreposição a elas, devem ser mantidas intactas, a fim de que o direito possa ser a dinâmica estruturante da própria política e da própria moral. A politização e a instrumentalização do direito e a colonização de ambos, do direito e da política, pela moral significam exatamente o fim do direito e de sua fundação na universalidade dos direitos humanos, bem como o fim do sistema político enquanto uma estrutura sistêmica que, na separação e na sobreposição de legislativo bicameral e executivo, se funda em um Estado democrático de direito determinante para seu desenvolvimento como sistema político, no qual a fundação na universalidade dos direitos humanos, a centralidade do pluralismo e do pluripartidarismo e, finalmente, a condição basilar do devido processo legal - o que significa tradução completa da política ao direito e enquadramento da política pelo direito - são os princípios estruturantes e definidores do sistema político democrático em sua condição antifascista, antitotalitária, não-fundamentalista e antirracista. Nesse sentido, mais uma vez, o direito não pode ser enquadrado, orientado e mesmo substituído pela política e pela moral, mas somente desde dentro do direito, desde sua fundação na universalidade dos direitos humanos e sua tradução ao direito. $\mathrm{O}$ direito é um conjunto sistêmico-sistemático-processual autossuficiente e autorreferencial, basicamente endógeno, e é essa dinâmica que permite a existência, a consolidação e o desenvolvimento da democracia pluralista e universalista como um sistema público de direito autorregulado, autorreflexivo, autocontrolado e autocorretivo que se funda apenas e tão somente na universalidade dos direitos humanos, na centralidade do pluralismo e na precedência, diferença, autonomia, autorreferencialidade e sobreposição do direito em relação à política e à moral (e, portanto, também na subsidiariedade da política e da moral ao direito e aos direitos humanos). No mesmo diapasão, a política e a moral, embora formem sistemas autoestruturados de modo completo, não são autorreferenciais, autossubsistentes e endógenas, em uma democracia pluralista e universalista, posto que são subsidiárias aos direitos humanos e ao direito, tendo de se justificar pública e institucionalmente sempre a partir de sua efetiva afirmação dos direitos humanos e da diferença-alteridade-diversidade, bem como só podendo manifestar-se privada, pública e institucionalmente sob a forma de tradução ao direito. É nesse sentido que falamos, ao longo deste capítulo, de que o direito não pode ser substituído, não pode ser reduzido, não pode ser produzido e nem pode ser enquadrado pela política e pela moral, mas apenas pelo próprio direito, ao passo que a política e a moral têm de ser enquadradas, reflexivizadas, fundadas, corrigidas e orientadas pelo direito, seja em termos de embasamento na universalidade dos direitos humanos, seja no que se refere à sua tradução ao procedimentalismo, à principialidade, à simbologia e à linguagem do direito positivo, seja, finalmente, em termos de controle de constitucionalidade e de responsabilização jurídico-social realizadas pelo judiciário frente ao sistema político (política formal) e à sociedade civil (política informal e morais particulares). A democracia pluralista e universalista é direito e só depois e como condição para tudo o mais, se ramifica em política (formal e informal, institucionalizada e nãoinstitucionalizada) e morais (sempre privadas) (cf.: Rawls, 2000a; Rawls, 2000b; Habermas, 2003a; Habermas, 2003b; Forst, 2010).

\section{O ESTADO DEMOCRÁTICO DE DIREITO ENQUANTO PERSPECTIVA SISTÊMICA, SISTEMÁTICA, MEDIAdA E PROCESSUAL ALTAMENTE INSTITUCIONALISTA, LEGALISTA, TECNICISTA, FORMALISTA E DESPERSONALIZADA}

Desta base fundacional da democracia, isto é, a universalidade dos direitos humanos, e desta sua lógica estruturante, a saber, a correlação de direitos humanos e direito e, portanto, a precedência ontogenética do direito em relação à política e à moral, a separação, a diferenciação, a autonomia, a 
independência, a endogenia, a autorreferencialidade, a autossubsistência, a autossuficiência e a sobreposição do direito no que se refere à política e à moral, a relação de subsidiariedade e de consequencialidade da política e da moral ao direito, bem como a necessidade de fundação plena delas nos direitos humanos e de sua tradução ao direito positivo, somos levados exatamente à constituição de um sistema público de direito demarcado por uma perspectiva sistemática, processual, mediada, instancial, progressiva e publicizada e centralizado em e dinamizado por uma postura altamente institucionalista, legalista, tecnicista, formalista e despersonalizada. Comecemos pela primeira parte. Trata-se, no caso da democracia pluralista e universalista, de um sistema público de direito: é um sistema porque, como estamos dizendo, se trata de um conjunto de instituições - judiciário e sistema político (legislativo, executivo e ministérios correlatos) - interligado e perpassado pela correlação de direitos humanos e direito; é um sistema na medida em que sua estruturação é lógico-técnica, formalista-despersonalizada e apolítico-despolitizada, isto é, um todo coerente e autoestruturado de modo necessário, previsível, controlado, programado e objetivo, sem qualquer possiblidade de espontaneísmo, personalismo e voluntarismo, o que significa que, enquanto sistema lógico-técnico, formalista-despersonalizado e apolítico-despolitizado, ele não aceita nenhuma postura interna antissistêmica, anti-institucional, antijurídica e infralegal, ademais de exigir que qualquer vinculação possível a ele, por parte de sujeitos sociopolíticos, se dê através do direito e, portanto, mais uma vez em termos legalistas, tecnicistas e formais; é um sistema público na medida em que ele não apenas está completamente visível e é plenamente acessível, verificável, compreensível e fiscalizável pelos sujeitos institucionalizados e pela sociedade civil, incluindo-se aqui a opinião pública, mas também porque é a única base estruturante de uma sociedade democrática pluralista e universalista, ou seja, somente as instituições públicas e sob a forma de um procedimento de institucionalização calcado no devido processo legal produzem objetividade normativo-jurídico-política, produzem universalidade $\mathrm{na} / \mathrm{como} /$ pela legalidade; e é um sistema público de direito exatamente porque está totalmente traduzido no procedimentalismo, na principialidade, na simbologia e na linguagem do direito positivo, bem como, antes de tudo, baseado radicalmente na correlação originária de direitos humanos e direito e demarcado profundamente pela condição ontogeneticamente primária, pela diferenciação, pela separação, pela autonomia, pela autossubsistência e pela sobreposição do direito em relação à política e à moral e pela subsidiariedade da política e da moral ao direito. A democracia pluralista e universalista, lembramos mais uma vez, é ontogeneticamente, antes de tudo e como condição para tudo o mais, direito, e só depois política e moral; ela é, portanto, um sistema público de direito desde o qual - e somente desde o qual - a política (formal e informal, institucionalizada e nãoinstitucionalizada) e as morais (sempre particulares, pertencentes à esfera privada da sociedade civil) são possíveis. $\mathrm{O}$ termo sistema público de direito, ou mesmo direito, tal como o estamos utilizando nesse texto, aponta para um conjunto de instituições, procedimentos, valores e práticas legalistas, quais sejam: direitos humanos, constituição política e direito positivo; judiciário e suas tarefas de controle de constitucionalidade e de responsabilização jurídico-social, com sua consequente atuação contramajoritária e sua diferenciação, autonomia, autossubsistência e sobreposição frente ao sistema político e à sociedade civil; as mediações jurídicas estruturantes e a ideia de um edifício jurídico escalonado e justaposto constituído por câmaras de revisão hierárquicas, dinamizado por recurso penal e direcionado à produção, à revisão, à correção e à confirmação processuais, consolidando jurisprudência objetiva, similaridade decisória e previsibilidade de aplicação da norma; e o devido processo legal público-publicizado.

Pois bem, esse sistema público de direito mais uma vez se contrapõe ao modelo fascista como sua antítese, como seu reverso completo, e isso em dois pontos: primeiramente, a lógica constitutiva, estruturante e dinamizadora do fascismo consiste na dinâmica moral-direito-moral, moral-política-moral e moral-cultura-moral, ou mesmo na dinâmica biologia-moral-biologia, biologiadireito-biologia, biologia-política-biologia e biologia-cultura-biologia, em que o direito é mero entreposto, mera consequencialidade, completamente subsidiário à correlação de moral e biologia, inexistindo, em verdade, separação, diferenciação e autonomia do direito frente à política e à moral aqui, o direito é mera moral materializada, mera moral militante, direcionado à guerra de exclusão justificada no dualismo-maniqueísmo moral; ademais, no dualismo-maniqueísmo fascista, temos um acesso direto, imediado e imediato do líder-partido-seita, sob a forma de uma iluminação pessoal interior, de uma visão privilegiada - e mais uma vez pessoal, direta e imediata - desse mesmo líderpartido-seita à verdade do mundo (a guerra de exclusão entre bons e maus, a corrupção do sistema público de direito, a degeneração das instituições, o sentido moralmente decaído da secularização do mundo profano), o que o impele de modo personalista, voluntarista, espontaneísta, vocacionado, missionário e messiânico a essa luta antissistêmica, anti-institucional, antijurídica e infralegal contra o 
sistema público de direito, contra seus inimigos políticos, negando-se toda e qualquer mediação jurídica, solapando-se direitos e garantias fundamentais, desestabilizando-se as instituições e a interseç̧ão, a diferenciação e a sobreposição entre poderes e deslegitimando-se o reconhecimento recíproco que é básico a uma democracia pluralista e universalista, diferenciada, heterogênea e complexa. Assim, o fascismo é imposição direta, imediada e imediata de uma guerra de exclusão recíproca fundada no dualismo-maniqueísmo moral e dinamizada por uma postura personalista com caráter antissistêmico, anti-institucional, antijurídico e infralegal do líder-partido-seita e de sua massamilícia digital-social de aclamação, os quais procuram colonizar moralmente e politizar o sistema público de direito, destruindo não só a co-originariedade de direitos humanos e direito e, assim, a primazia ontogenética, a autonomia, a autossubsistência e a sobreposição do direito em relação à política e à moral e a subsidiariedade da política e da moral ao direito, mas também seja a própria institucionalidade, legalidade, tecnicalidade, formalidade e despersonalização do sistema público de direito, seja mesmo a pluralização, diferenciação, heterogeneidade e complexidade sociopolíticas que são gerenciadas e orientadas por esse mesmo sistema público de direito (cf.: Fanon, 1968; Fanon, 2008; Césaire, 1978; Memmi, 1967; Mbembe, 2014a; Mbembe, 2014b; Nascimento, 2016). Nesse caso, um sistema público de direito subvertido institucionalmente desde dentro já não consegue mais produzir universalidade na/como/pela legalidade, senão que, refém do autoritarismo político, do racismo estrutural e do fundamentalismo religioso, está direcionado ao lawfare institucional, à polícia de Estado e ao Estado de exceção contra adversários e ao correlato silenciamento, invisibilização e deslegitimação da universalidade dos direitos humanos e da alteridade, bem como de suas lutas e de todo o trabalho institucional em torno à construção e à implantação de processos de reconhecimento, inclusão e participação destinados a resolver os problemas de integração institucional e social em torno aos direitos humanos e ao pluralismo, ainda deficitários - e agora, com o fascismo hegemônico institucionalmente e através de sua implosão desde dentro do sistema público de direito, demarcados (os direitos humanos, o pluralismo e o direito) pela regressão totalizante.

Em contrapartida, o sistema público de direito democrático, calcado na afirmação do pluralismo-diversidade-alteridade, fundado na universalidade dos direitos humanos e dinamizado e estruturado em termos da correlação originária de direitos humanos e direito, de primazia ontogenética, separação, diferenciação, autonomia, autossuficiência e sobreposição do direito em relação à política e à moral e de subsidiariedade da política e da moral ao direito, consolida-se como um conjunto de instituições e um procedimento de institucionalização com caráter sistemático, processual, mediado, instancial, progressivo e publicizado, o qual leva, então, exatamente à produção autorreflexiva, autocontrolada e autocorretiva da universalidade na/como/pela legalidade, em termos de materialização da universalidade dos direitos humanos em direitos e garantias fundamentais e segurança, isonomia, simetria e horizontalidade jurídicas, a partir do compartilhamento de tarefas entre judiciário, que realiza controle de constitucionalidade e responsabilização jurídico-social, e sistema político, o qual, na intersecção e na sobreposição do legislativo bicameral em relação ao executivo, produz políticas públicas, previsão constitucional e principialidade jurídica - com judiciário e sistema político tendo de agir de modo contramajoritário, por causa de sua fundação exclusiva, suficiente e necessária na universalidade dos direitos humanos e sua completa tradução ao direito. Note-se essa atuação sistemática, processual, mediada, instancial, progressiva e publicizada de nossas instituições públicas, de nosso sistema público de direito no que tange à produção da objetividade normativojurídico-política; note-se, além disso, que é tal postura sistemática, processual, mediada, instancial, progressiva e publicizada que permite um trabalho autocorretivo, autocontrolado e autorreflexivo desse e por esse mesmo sistema público de direito, dessas e por essas mesmas instituições públicas, sendo que é essa dinâmica que lhes constitui enquanto perspectiva antifascista, antitotalitária, nãofundamentalista e antirracista (cf.: Rawls, 2003; Rawls, 2000c; Habermas, 2002a; Habermas, 2002b; Honneth, 2003). Nesse ponto, começam a aparecer as especificidades e, portanto, as diferenças apresentadas pela democracia pluralista e universalista constituída enquanto um sistema público de direito relativamente ao fascismo. A primeira diferença, obviamente, como já comentamos acima, diz respeito à lógica estruturante da democracia, que consiste na dinâmica direito-moral-direito, direitopolítica-direito e direito-cultura-direito, no sentido de que, pela sua correlação exclusiva, suficiente e necessária aos direitos humanos, o direito é a própria materialização dos direitos humanos e, por isso mesmo, tem primazia ontogenética, autorreferencialidade, autossubsistência, independência, separação e sobreposição à política e à moral - de modo que a democracia, nesta sua lógica estruturante, é, antes de tudo e como condição para tudo o mais, direito, e só depois política e moral. Esta lógica significa, portanto, que todo o trabalho das instituições públicas e dos sujeitos institucionalizados, seja o/no judiciário, seja o/no sistema político, bem como todas as posições políticas (formais e informais) $e$ 
todas as posições morais (sempre privadas, particulares), têm de fundar-se necessariamente na universalidade dos direitos humanos e traduzir-se completamente no procedimentalismo, na principialidade, na simbologia e na linguagem do direito positivo. Isso também significa que, na democracia pluralista e universalista constituída como sistema público de direito, (a) os direitos humanos são a base normativa fundacional seja das instituições públicas, seja da sociedade civil (a única, exclusiva, suficiente e necessária base, aliás), (b) todos e cada um precisam, tanto em sua esfera privada quanto em sua vinculação público-institucional, traduzir-se ao direito positivo e (c) o sistema público de direito, por meio do devido processo legal, da intersecção, do compartilhamento de tarefas e da sobreposição do judiciário frente ao sistema político, é a única instância para a produção da objetividade normativo-jurídico-política. É aqui que entra essa perspectiva institucionalista, legalista, tecnicista, formalista e despersonalizada com caráter sistemático, processual, mediado, instancial, progressivo e publicizado que, como dissemos, é a condição democrática basilar para a construção da universalidade na/como/pela legalidade enquanto possuindo um sentido antifascista, antitotalitário, não-fundamentalista e antirracista.

A perspectiva sistemática própria ao direito de um modo geral e ao judiciário e ao sistema político em particular (inclusive necessária também à sociedade civil, mas estamos nos referindo, agora, ao sistema público de direito, às instituições públicas) significa não só que judiciário e sistema político agem como um conjunto institucional previsível, controlável e programável em termos lógicotécnicos, em que da universalidade dos direitos humanos vamos à particularização material seja em termos de direitos e garantias fundamentais, seja no que se refere à efetivação de procedimentos que garantam a realização deles em cada espaço e desafio mínimos emergentes nas sociedades democráticas, colocados pela pluralidade, mas também e principalmente, para o que nos interessa agora, que a produção da objetividade normativo-jurídico-política se dá passo a passo, princípio a princípio, etapa após etapa, a qual é produzida processualmente. Por processualidade, entendemos tanto a ideia de que o devido processo legal é o único instrumento da democracia pluralista e universalista e de seu sistema público de direito seja para sua materialização, seja para esse trabalho de construção da universalidade na/como/pela legalidade, quanto de que o trabalho institucional de produção da objetividade normativo-jurídico-política, internamente ao judiciário e ao sistema político e na intersecção e sobreposição entre ambos, está formalizado sistemicamente e objetivado textualmente, com fundamentação, argumentação, contra-argumentação, prova empírica, avaliação jurídico-constitucional, revisão, correção e confirmação de sentença, bem como recurso penal permanente e tramitação escalonada e verticalizada. Note-se que, no caso dessa perspectiva institucional, legal, técnica, formal e despersonalizada própria ao direito de um modo geral e ao judiciário e ao sistema político em particular, temos um trabalho instancial e progressivo, progressivo porque instancial, em que cada estrato do edifício jurídico e do edifício político, nas suas especificidades (embora sempre demarcados, orientados e geridos pelo direito), funda, revisa, corrige, complementa e, então, confirma a objetividade normativo-jurídico-política a partir do devido processo legal público-publicizado, possibilitando, por isso mesmo, de modo último, tanto a fiscalização, o controle, o conhecimento e a compreensão públicos pelos sujeitos de direito e pela opinião pública quanto a consolidação de jurisprudência objetiva, similaridade decisória e previsibilidade de aplicação da norma, garantidoras da isonomia, da segurança, da horizontalidade e da simetria jurídicas para todos e entre todos. Nesse sistema público de direito, através da correlação de direitos humanos e direito, de diferenciação, autonomia, autossubsistência e sobreposição do direito em relação à política e à moral e de consentânea autonomia, separação, diferenciação e sobreposição do judiciário em relação ao sistema político, marcado pelo devido processo legal, temos a consolidação de um poder institucional que não apenas é programável, previsível e regulado legal, técnica e logicamente, ademais de exercido formal e despersonalizadamente, senão que também apresenta exatamente mediações múltiplas que têm por meta tanto refrear tendências autoritárias e fascistas dentro dos sistemas sociais e mesmo fora deles, as quais possuem sentido disruptivo das instituições, violador do direito e negador do pluralismo, quanto garantir que a produção do devido processo legal aconteça de modo idôneo, revisado, técnico e seja equalizada relativamente a todos os sujeitos de direito, protegendo-se, fomentando-se e realizando-se os direitos e as garantias fundamentais e, então, a isonomia, a segurança, a simetria e a horizontalidade jurídicas (cf.: Habermas, 2003a; Habermas, 2003b; Rawls, 2003; Rancière, 2014). O sistema público de direito, centralizado no direito e dinamizado apenas por meio do devido processo legal, é completamente mediado e se realiza gradualmente, de modo seriado e progressivo, sendo demarcado, como dissemos, (a) por instâncias consecutivas, sobrepostas e justapostas, em que as câmaras de revisão, hierarquicamente situadas, produzem, revisam, corrigem e confirmam o resultado processual, bem como (b) pela divisão de 
tarefas e pela separação, diferenciação e sobreposição entre judiciário e sistema político, do judiciário sobre o sistema político, inclusive pela existência de uma opinião pública crítica do poder (amplificada, em vários sentidos, pelas mídias digitais e alternativas), em que o direito controla a política e a moral, o judiciário enquadra e reflexiviza o sistema político, da mesma forma como este, por meio do direito, reflexiviza o judiciário (embora o judiciário somente possa se corrigir desde dentro, em termos dessa instancialidade recursal, das câmaras de revisão e da hierarquia processual) no mesmo sentido, a opinião pública e os sujeitos sociopolíticos podem acionar as instituições por meio dos canais oficiais de contato e de interação (conselhos, corregedorias, ouvidorias e até mesmo projetos de lei de autoria popular), instando-as a corrigirem déficits institucionais e sociais. Como dissemos, por meio do direito, em termos do devido processo legal e a partir da diferenciação, da autonomia e da sobreposição do judiciário em relação ao sistema político, a democracia torna-se poder indireto, controlado, reflexivo, programado, visível e fiscalizado, demarcado por sistematicidade, processualidade, mediações, instancialidade, progressividade e publicidade.

Ademais, o sistema público de direito também é constituído enquanto uma perspectiva altamente institucionalista, legalista, tecnicista, formalista e despersonalizada que tem por meta erradicar o personalismo, o espontaneísmo e o voluntarismo jurídico-políticos e suas posturas antissistêmicas, anti-institucionais, antijurídicas e infralegais desde dentro das instituições e ramificando-se para a sociedade civil. Com efeito, uma das grandes características da versão contemporânea, da "versão século XXI" do fascismo consiste exatamente na politização e na partidarização do direito por seus próprios operadores, isto é, na implosão do judiciário desde dentro em termos de personalismo, voluntarismo e messianismo jurídico-político antissistêmico, antiinstitucional, antijurídico e infralegal que, por meio do lawfare institucional e da polícia de Estado, alia-se diretamente e toma partido pungentemente na luta político-partidária fratricida no âmbito do sistema político, produzindo, para viabilizar essa violação do sistema judiciário e essa politizaçãopartidarização do direito, uma massa-milícia digital-social de aclamação que, enquanto extensão corporal manobrável politicamente, confere, via populismo contramajoritário, o respaldo à implosão interna do sistema jurídico e, desde ele e por seu protagonismo, do próprio sistema político. Note-se que esse fascismo versão século XXI também assume elementos próprios ao modelo clássico do fascismo próprio à primeira metade do século $\mathrm{XX}$, em particular a correlação de personalismo do poder, centralizado, monopolizado e manifestado por parte do líder-partido-seita-cabeça, de dualismomaniqueísmo-moral negador da diferença, dos direitos e das garantias fundamentais e das mediações jurídico-institucionais e, então, de criação, de sustento e de estímulo dessa massa-milícia digital-social de aclamação que realiza atitudes de fragilização institucional desde a sociedade civil, complementares à subversão fascista do sistema público de direito desde dentro. Nesse sentido, no caso do sistema público de direito próprio à democracia pluralista e antifascista, nós temos a forte ênfase na postura institucionalista, legalista, tecnicista, formalista e despersonalizada de que falamos acima, a qual leva a uma perspectiva axiológico-procedimental-metodológica imparcial, impessoal e neutra centralizada na promoção da universalidade dos direitos humanos, na co-originariedade de direitos humanos e direito, na tradução completa das instituições ao direito positivo e na assunção do caráter basilar do devido processo legal, com a separação, a diferenciação e a sobreposição do judiciário em relação ao sistema político. Aqui, a dinâmica sistêmica institucionalista, legalista, tecnicista, formalista e despersonalizada objetiva, primeiramente, garantir seja a correlação originária entre direitos humanos e direito, seja a completa tradução das instituições públicas ao direito e sua manifestação apenas no/como/pelo devido processo legal, seja, por conseguinte, a autonomia, a diferenciação, a autossubsistência e a sobreposição do direito frente à política e à moral, com a consequente subsidiariedade destas àqueles. Por isso mesmo, enquanto perspectiva altamente institucionalista, legalista, tecnicista, formalista e despersonalizada, o judiciário e o sistema político são somente direito e se dão, se constituem, se vinculam e se manifestam objetivamente apenas através do direito. A efetiva centralidade do pluralismo-diversidade e a consequente afirmação da universalidade dos direitos humanos exige exatamente instituições públicas fundadas, constituídas, legitimadas e dinamizadas exclusivamente pelo direito, no direito, como direito, independentes e autorreferenciais frente à política e à moral essencialistas, naturalizadas e pré-jurídicas e, portanto, com capacidade de atuação contramajoritária e com poder e legitimidade para obrigar que as posições político-morais fundem-se na universalidade dos direitos humanos e traduzam-se completamente ao direito positivo. Somente os direitos humanos, o direito positivo e, então, o sistema público de direito altamente institucionalista, legalista, tecnicista, formalista e despersonalizado conseguem fazer efetivo jus ao pluralismo, à diversidade e à alteridade e, assim, à primazia do direito em relação à política e às morais. E, então, somente essa perspectiva sistêmica, sistemática, processual, mediada, instancial, progressiva e publicizada consegue garantir 
uma produção autorreflexiva, autocorretiva e autocontrolada da objetividade normativo-jurídicopolítica por parte das instituições e na correlação, na diferenciação, na separação e na sobreposição de judiciário e sistema político, uma vez que exige a consecução gradativa de passos, princípios e dinâmicas estruturantes que possuem exatamente um sentido lógico-técnico, formalistadespersonalizado e apolítico-despolitizado, evitando-se, nesse caso, posturas antissistêmicas, antiinstitucionais, antijurídicas e infralegais assumidas por sujeitos formais personalistas e voluntaristas que reduzem o direito a mero instrumento político-moral e, com isso, subordinam o judiciário ao sistema político, destruindo a especificidade, a separação, a diferenciação, a autonomia, a autorreferencialidade e a sobreposição do direito em relação à política e à moral e, obviamente, do judiciário frente ao sistema político.

No mesmo diapasão, a dinâmica sistêmica altamente institucionalista, legalista, tecnicista, formalista e despersonalizada do (e necessária ao) judiciário e do (e necessária ao) sistema político objetiva, em segundo lugar, garantir exatamente previsibilidade, programação, objetividade e efetividade à postura sistêmica, sistemática, processual, instancial, progressiva, mediada e publicizada própria mais uma vez ao judiciário e ao sistema político, exigida sempre e pungentemente ao judiciário e ao sistema político. Com efeito, lembremos mais uma vez que a democracia pluralista e universalista constituída enquanto um Estado democrático de direito ou como um sistema público de direito tem como alvo principal o fascismo e o totalitarismo, assim como o racismo e o fundamentalismo, que são as bases normativas dinamizadoras desse mesmo fascismo-totalitarismo. De modo mais específico, o sistema público de direito, nessa sua tripla característica, (a) co-originariedade de direito e direitos humanos e condição ontogeneticamente primária, diferenciada, separada, autônoma, autossuficiente e sobreposta do direito em relação à política e à moral (e subsidiariedade destas em relação àquele), (b) perspectiva sistêmica, sistemática, processual, mediada, instancial, progressiva e publicizada do judiciário e do sistema político e (c) postura altamente institucionalista, legalista, tecnicista, formalista e despersonalizada dos sistemas sociais direito e política, é erigido no sentido de garantir uma produção autorreflexiva, autocontrolada e autocorretiva da universalidade na/como/pela legalidade e, com isso, tem como foco evitar o personalismo jurídico-político voluntarista, espontaneísta e heroico dos sujeitos institucionalizados e dos aventureiros políticos de plantão, deslegitimando atuações antissistêmicas, anti-institucionais, antijurídicas e infralegais primeiramente dentro das próprias instituições sistêmicas e por parte dos sujeitos institucionalizados ou formais e, depois, no contexto da própria sociedade civil e por parte dos sujeitos informais. É nesse sentido que falamos, acima, que a neutralidade, a imparcialidade, a formalidade, a tecnicalidade e a logicidade institucionais, fundadas no direito e traduzidas completamente ao procedimentalismo, à principialidade, à simbologia e à linguagem do direito positivo, garantem uma produção processual previsível, controlada, programada e mediada, capaz de ser visibilizada e fiscalizada por todos, das instituições à sociedade civil e desta para aquelas. O líder-partido-seita fascista, dado seu voluntarismo e sua atuação antissistêmica, é completamente imprevisível nas suas ações, posto que não reconhece a limitação institucional efetivada pelas mediações jurídicas estruturantes, pela instancialidade, pela progressividade e pela hierarquia no que diz respeito à produção processual, pela separação e sobreposição entre poderes e, finalmente, pelo reconhecimento da igualdade de todos (tanto formal quanto material). O líder-partidoseita personalista é vontade absoluta e ilimitada e ação imediata, imediada e direta com caráter imoderado, sem qualquer tradução ao direito, rompendo com o devido processo legal e, nesse caso, por meio da supressão pura e simples das mediações estruturantes, destruindo qualquer possibilidade de uma atuação institucional programada e coerente desde uma condição institucional técnica, lógica, legalista, imparcial, impessoal e neutra. Aqui, no fascismo e por meio de sua atuação personalista e voluntarista, bem como por suas posturas antissistêmicas, as instituições deixam de ter efetiva validade e funcionamento enquanto um sistema público de direito, tornando-se mero entreposto, mera extensão do ilimitado político-moral que coloniza e instrumentaliza os poderes públicos, eliminando a diferença e a centralidade do direito - e do Estado de direito - frente à política e à moral, as quais adquirem, ademais, um sentido missionário, messiânico, salvífico e escatológico em termos de guerra de exclusão recíproca (cf.: Fanon, 1968; Fanon, 2008; Césaire, 1978; Mbembe, 2014b).

É exatamente por isso, aliás, que nós temos, no caso do fascismo, uma postura antissistêmica destinada a derrubar as instituições e, com elas, a solapar e a desestabilizar o sistema público de direito, sua base normativa universalista e suas mediações jurídicas estruturantes. Como estamos percebendo ao longo do texto, o sistema público de direito (a) obriga todas as instituições e os sujeitos institucionalizados ou formais, bem como toda a sociedade civil e os sujeitos nãoinstitucionalizados ou informais, seja a fundarem-se na universalidade dos direitos humanos, seja a traduzirem-se no procedimentalismo, na principialidade, na simbologia e na linguagem do direito 
positivo em termos de legitimidade privada e público-institucional, (b) implica em uma perspectiva institucional sistêmica, sistemática, processual, mediada, instancial, progressiva e publicizada que demanda separação e sobreposição entre poderes, controle legal e técnico recíproco e produção gradual, seriada, sequencial e consequencial, demarcada ademais por hierarquia processual, da objetividade normativo-jurídico-política, bem como (c) exige do judiciário e do sistema político (e, por conseguinte, de todos os sujeitos institucionalizados) uma atuação altamente institucionalista, legalista, tecnicista, formalista e despersonalizada, o que implica não só na neutralidade, na imparcialidade e na impessoalidade institucionais, mas também nessa condição lógica do devido processo legal e dos atos administrativos, constituídos em termos de uma cadeira programada, previsível e consequencial de princípios estruturantes que vão dos direitos humanos para a constituição política, desta para o direito positivo e deste para a especificidade, a interrelação, a separação e a sobreposição do judiciário em relação ao sistema político, do direito frente à política e à moral. Ora, estas três condições fundadoras, estruturantes, definidoras e legitimadoras do sistema público de direito lhe permitem erradicar o fascismo interno às instituições, o fascismo desde dentro das instituições, uma vez que vincula os sujeitos institucionalizados e os atos processual-administrativos à legalidade, à tecnicalidade, à formalidade e à despersonalização, exigindo prova e contraprova, argumentação e contraargumentação objetivas, justificadas constitucional e juridicamente e embasadas empiricamente, de modo correlato a essa neutralidade, imparcialidade, impessoalidade e formalidade institucionais inclusive viabilizando sempre o acionamento do judiciário relativamente ao sistema político e sob a forma de controle de constitucionalidade e responsabilização jurídico-social; e também lhe permitem erradicar o fascismo externo às instituições, o fascismo desde fora das instituições, uma vez que o exemplo estrito do judiciário e do sistema político (principalmente o judiciário) em termos de fundação na universalidade dos direitos humanos, de separação, diferenciação, autonomia, autorreferencialidade e sobreposição do direito no que se refere à política e à moral, de devido processo legal, de sistematicidade, mediações e publicidade institucional e de institucionalidade, legalidade, tecnicalidade, formalidade e despersonalização sistêmicas conferem força plena e completa legitimidade ao judiciário e ao sistema político em agirem de modo contramajoritário.

Isso é especialmente verdade ao judiciário, que se sustenta e se sobrepõe ao sistema político e enfrenta as tendências antissistêmicas disruptivas emergentes da sociedade civil (e dos próprios partidos e lideranças políticas, obviamente) concomitantemente, correlatamente à intensidade com que de fato está separado, autônomo, autossuficiente e independente ao sistema político e à sociedade civil, focado única e exclusivamente na universalidade dos direitos humanos e na efetivação da constituição política por meio do direito positivo, do devido processo legal e do ideal de institucionalidade, legalidade, tecnicalidade, formalidade e despersonalização sistêmicas, inclusive embasando sua postura sistêmica na imparcialidade, na impessoalidade, na neutralidade e na apoliticidade-despolitização institucional-axiológicas. No caso do judiciário, aliás, que é a base estruturante e dinamizadora do sistema público de direito e a pedra angular validadora da produção institucional da objetividade normativo-jurídico-política e da dialética pluralizadora, diferenciadora, heterogeneizadora e complexificadora própria à sociedade civil e entre os, pelos múltiplos sujeitos sociopolíticos, é questão de vida e de morte a correlação originária de direitos humanos e direito e, portanto, a sua (do judiciário) tradução completa ao procedimentalismo, à principialidade, à simbologia e à linguagem do direito positivo, bem como, consentaneamente, a realização seja de sua postura sistemática, processual, mediada, instancial, progressiva e publicizada, seja de seu ideal forte de institucionalidade, legalidade, tecnicalidade, formalidade e despersonalização metodológicoaxiológicas. O judiciário é o baluarte de uma democracia em termos de defesa, de contenção $e$ de deslegitimação do fascismo, do totalitarismo, do racismo e do fundamentalismo, o que exige a universalidade dos direitos e das garantias fundamentais e a efetividade da segurança, da isonomia, da simetria e da horizontalidade jurídicas, a existência e o funcionamento das mediações jurídicas estruturantes, a centralidade do devido processo legal como o único instrumento institucional e social para a produção da objetividade jurídico-político-normativa e, então, a separação e a sobreposição do direito em relação à política e à moral. E isto significa que ele, o judiciário, é a base institucional desde a qual o personalismo jurídico-político antissistêmico, anti-institucional, antijurídico e infralegal é desconstruído e invalidado no que tange à estruturação e à atuação do sistema público de direito. Nesse sentido, esse mesmo judiciário precisa, antes de tudo e como condição para tudo o mais em termos de estabilização institucional, de controle, de enquadramento e de orientação do sistema político e, finalmente, de organização e de legitimação institucionais da sociedade civil, dar o exemplo de institucionalidade, legalidade, tecnicalidade, formalismo e despersonalização, assumindo a correlação originária de direitos humanos e direito e focando exatamente no devido processo legal 
público, assumindo um sentido apolítico-despolitizado, formalista-despersonalizado e lógico-técnico e uma postura imparcial, impessoal, neutra e apolítico-despolitizado estruturais e estruturantes, como condição para tudo o mais, seja internamente ao judiciário, seja no que se refere ao sistema político e à sociedade civil. Note-se bem: o judiciário deve dar o exemplo de respeito, de atenção e de promoção do sistema público de direito de um modo geral e de fundação na universalidade dos direitos humanos, de tradução ao direito positivo, de foco no devido processo legal e de separação, autonomia e sobreposição do direito frente à política e à moral em particular, se efetivamente quiser assumir e implantar a sua centralidade e a própria centralidade do direito no que diz respeito a sociedades democráticas pluralistas e antifascistas - inclusive se quiser de fato assumir legitimidade em sua atuação contramajoritária em termos de controle de constitucionalidade e responsabilização jurídicosocial, seja frente ao sistema político, seja no que se refere à sociedade civil. Nesse caso, se o sistema público de direito, na correlação originária de direitos humanos e direito, na centralidade do devido processo legal e no ideal público de institucionalidade, de legalidade, de tecnicalidade, de formalidade e de despersonalização metodológico-procedimental-axiológicos, foi construído para produzir de modo reflexivo, controlado e corretivo a universalidade na/como/pela legalidade enquanto a única maneira de se constituir uma sociedade, uma cultura e instituições democráticas antifascistas, antitotalitárias, não-fundamentalistas e antirracistas, então cabe ao judiciário o exemplo e a atitude fundacionais dessa mesma democracia em termos de embasamento na universalidade dos direitos humanos, na centralidade do pluralismo-diversidade e no caráter estruturador do devido processo legal público-publicizado. Por outras palavras, é do judiciário que devem partir os exemplos e os impulsos auto-organizativos da democracia enquanto perspectiva antifascista, antitotalitária, nãofundamentalista e antirracista (cf.: Habermas, 2003a; Rawls, 2000a; Rancière, 2014). Parafraseando Ivan Karamazov, personagem do romance Os irmãos Karamazov, de Fiódor Dostoiévski, parafraseando-o por outros meios, é claro, se o judiciário é antifascista, antitotalitário, nãofundamentalista e antirracista, então toda a democracia pluralista e universalista constituída enquanto um sistema público de direito também é antifascista, antitotalitária, não-fundamentalista e antirracista; se o judiciário é fascista e antissistêmico, então toda a degeneração fascista mais ampla, dentro e fora das instituições, está permitida e, na verdade, incentivada pelo próprio judiciário.

\section{JUdiCIALIZAÇÃo da POLÍTICA E POLITIZAÇÃo DO DIREITO: O QUE É E O QUE NÃO É CONDUTA SISTEMICAMENTE VÁLIDA AO ESTADO DEMOCRÁTICO DE DIREITO}

A correlação originária e o aparecimento concomitante de direitos humanos e direito implicam em que a democracia pluralista e universalista é, antes de tudo e como condição para tudo o mais, direito e, então, sistema público de direito, e só depois política e moral, só depois sistema político de direito e dialética social entre posições político-morais em interação/disputa. Por direito, entendemos essa ideia de um sistema público de direito completo, autoestruturado e independente, que começa exatamente como direitos humanos e se ramifica em constituição política e direito positivo; se materializa e se objetiva em termos das instituições públicas, no caso o judiciário e o sistema político (legislativo bicameral e executivo), sob a dinâmica de correlação (ambos são interdependentes e se direcionam à materialização dos direitos humanos em direitos e garantias fundamentais e segurança, isonomia, simetria e horizontalidade jurídico-políticas), divisão de tarefas (judiciário realiza controle de constitucionalidade e responsabilização jurídico-social e sistema político tem por escopo a produção de políticas públicas, de previsão constitucional e de principialidade jurídica, ambos atuando de modo contramajoritário), separação, diferenciação e sobreposição do judiciário em relação ao sistema político e do legislativo bicameral em relação ao executivo; se centraliza e se manifesta objetivamente em termos do devido processo legal como seu único instrumento construtivo; passa pela constituição de edifícios sistêmicos demarcados por sistematicidade, processualidade, mediações, instancialidade, progressividade e publicidade, demarcados por revisão, correção e confirmação de sentença; se vincula a uma ordem internacional de direito, ao direito internacional e, no caso, ao Estatuto de Roma do Tribunal Penal Internacional (inserindo-se, portanto, em uma ordem universalista de direito); e, em tudo isso, é dinamizado pela e direcionado à produção autorreflexiva, autocontrolada e autocorretiva da universalidade na/como/pela legalidade. O sistema público de direito tem por meta a produção da universalidade na/como/pela legalidade. Esta definição já nos permite pensarmos as questões de judicialização da política e de politização do direito como, respectivamente a característica mais básica das lutas democráticas e da correlação, da divisão de tarefas, da separação, da 
diferenciação, da autorreferencialidade e da sobreposição do judiciário em relação ao sistema político, no caso da judicialização da política, e como a postura mais destrutiva da centralidade, da estabilidade e da legitimidade do sistema público de direito, quando pensamos na politização do direito - porque, neste caso, destrói-se a base normativa fundacional e estruturante da democracia, a saber, a separação, a diferenciação, a autonomia, a independência, a endogenia, a autorreferencialidade, a autossubsistência, a autossuficiência e a sobreposição do direito em relação à política e à moral, com a consequente subsidiariedade destas em relação àquele e, por conseguinte, sua (da política e da moral) necessidade de fundação completa na universalidade dos direitos humanos e de tradução plena no procedimentalismo, na principialidade, na simbologia e na linguagem do direito positivo.

Como já desenvolvemos acima, é dessa correlação originária e dessa emergência concomitante de direitos humanos e direito que todo o sistema público de direito se estrutura seja no que se refere à sua constituição sistemática, processual, mediada, instancial, progressiva e públicopublicizada, seja no que se refere ao seu forte ideal de institucionalidade, legalidade, tecnicalidade, formalidade e despersonalização sistêmicas, seja, finalmente, em sua perspectiva axiológica imparcial, impessoal e neutra. Na verdade, esses três eixos sistêmicos próprios ao direito, como direito e possibilitados pelo direito têm por meta garantir exatamente que a política (formal e informal) e a moral (sempre privada) sejam contidas, estejam embasadas e sejam direcionadas pelo objetivo - pelo único objetivo democrático - de materialização dos direitos humanos dentro dos trilhos do direito e de modo a se assumir, fortalecer e efetivar o Estado democrático de direito. Não é mero acaso, aqui, que o judiciário seja a instituição central e a pedra angular validadora da própria democracia como um todo, na medida em que é seu objetivo colocar a política e a moral nos trilhos do direito, direcionadas à materialização dos direitos humanos e dinamizadas no caminho estabelecido pelo Estado democrático de direito. $\mathrm{O}$ direito e o sistema público de direito, o direito no/como/pelo sistema público de direito tem por meta a proteção e o fomento da universalidade dos direitos humanos e do pluralismo; e ele assim o faz por meio do enquadramento, da reflexivização, do controle e da correção do sistema político e da sociedade civil, de modo que, mais uma vez, o direito é a base ontogenético-normativa constitutiva, reflexiva e dinamizadora da política e da moral. Ora, o primeiro passo dessa colocação das perspectivas político-morais democráticas nos trilhos da própria democracia (como eticidade póstradicional) e do próprio Estado democrático de direito (como sistema público de direito) consiste exatamente na fundação da política e da moral na universalidade dos direitos humanos e de sua tradução ao direito positivo. Sem isso, não pode haver efetivamente posições político-morais democráticas, mas exatamente fascismo totalizante e imparável. A fundação da política e da moral na universalidade dos direitos humanos e sua tradução ao direito permitem-lhes moderarem-se e limitarem-se tanto desde dentro quanto, sempre que for o caso, desde fora, desde o próprio aparato público de justiça e de seus valores e procedimentos constitutivos, representados e realizados em termos de judiciário. O segundo passo basilar para a constituição, a validação e a vinculação públicoinstitucional das posições político-morais democráticas consiste na afirmação da neutralidade, da impessoalidade, da imparcialidade e da formalidade procedimentais, no sentido de que seu contato com instituições públicas e sua vinculação à esfera pública democrática têm de acontecer sob a forma de uma perspectiva axiológica que assume o universalismo pós-tradicional e, portanto, sua condição não-etnocêntrica e não-egocêntrica, sob a forma exatamente dessa neutralidade, dessa impessoalidade e dessa imparcialidade axiológicas e dessa formalidade procedimental-metodológica. As instituições públicas democráticas e, na radicalidade, o próprio espaço público democrático não são lugares de militância personalista, voluntarista, espontaneísta, missionária e messiânica, feitas de qualquer modo e por quaisquer meios e direcionadas pura e simplesmente à hegemonia de interesses privados (que, em muitas situações, colocam em xeque a própria existência do pluralismo, dos direitos humanos e do Estado democrático de direito), em prol de (e com base em) perspectivas pré-jurídicas, antimodernas e antidemocráticas, principalmente no que se refere às próprias instituições públicas e desde elas. Vinculações público-institucionais, de todo e qualquer sujeito-grupo sociopolítico, só se dão em nome dos direitos humanos e sob a forma de tradução ao direito. Aliás, aqui está o terceiro ponto importante garantidor da legitimidade e da validade público-institucional - e privada, obviamente - das posições político-morais formais e informais, a saber, a sua manifestação objetiva em termos do devido processo legal. Note-se, nesse caso, que o devido processo legal não é apenas o único, exclusivo e suficiente instrumento público de manifestação e de objetivação das e pelas instituições públicas, dos e pelos sujeitos institucionalizados. Ele também é o único instrumento formal-material para a vinculação, a manifestação e a objetivação público-institucionais de toda e qualquer posição políticomoral e de todo e qualquer sujeito informal, os quais, portanto, precisam exatamente formalizar-se para garantir validade pública e institucional (e inclusive privada, no âmbito do direito privado, na 
esfera das relações comunitárias e/ou privadas). O devido processo legal congrega não apenas a fundação, o respeito, a afirmação e a promoção da universalidade dos direitos e das garantias fundamentais e da segurança, da isonomia, da simetria e da horizontalidade jurídicas, mas também a valorização das mediações jurídicas estruturantes, a aceitação e a utilização do ideal de institucionalidade, legalidade, tecnicalidade, formalidade e despersonalização sistêmicas, a ênfase na sistematicidade, na processualidade, nas mediações, na instancialidade, na progressividade e na publicidade das instituições e da própria sociedade civil democrática, bem como, enquanto fecho de abóboda de tudo isso, tanto a perspectiva de neutralidade, imparcialidade e impessoalidade metodológico-axiológicas quanto a subsidiariedade da política e da moral ao direito e, nesse caso, a condição ontogeneticamente primária do direito em relação à política e à moral, com sua correlação direta à universalidade dos direitos humanos.

Ora, mais uma vez entra em cena todo o trabalho estruturador, mediador, orientador e gestor das relações entre direito, política e moral, entre posições político-morais próprias à sociedade civil e instituições públicas, por parte do judiciário enquanto o guardião do Estado democrático de direito na sua correlação de direitos humanos, tecnicalidade jurídica, procedimentalismo processual, separação entre poderes e instituições públicas. No mesmo diapasão, é exatamente por essa centralidade enquanto guardador dos direitos humanos, do pluralismo e do sistema público de direito, incluindo-se, aqui, das relações e especificidades entre direito, política e moral, que recaem ao judiciário as responsabilidades mais pesadas no que concerne (a) à primazia ontogenética, à separação, à diferenciação, à autonomia, à autorreferencialidade e à sobreposição do direito em relação à política e à moral (com a subsidiariedade destas em relação àquele), (b) à efetivação dessa condição sistêmica, sistemática, mediada, processual, instancial, progressiva e público-publicizada do judiciário, do sistema político e da sociedade civil, entre judiciário, sistema político e sociedade civil, (c) à perspectiva altamente institucionalista, legalista, tecnicista, formalista e despersonalizada a ser assumida pelo judiciário e pelo sistema político (e até pela própria sociedade civil, na medida em que as posições político-morais, formais e informais, precisam traduzir-se ao direito positivo em termos de sua validade e vinculação público-institucionais) e (d) à imparcialidade, à impessoalidade, à neutralidade e à apoliticidade-despolitização axiológicas. Todo este conjunto de passos, princípios e valores estruturantes somente pode ser legitimado, sustentado e promovido ao longo do tempo se o judiciário conseguir, primeiramente, assumi-lo, sustentá-lo, promovê-lo, legitimá-lo e implantá-lo para si mesmo, desde dentro, entre suas instâncias, hierarquias e câmaras de revisão, no contexto de todo o seu edifício institucional instancial, justaposto, processual e hierárquico.

Sobre isso, é importante desenvolvermos dois pontos. O primeiro deles diz respeito à supercapacidade sistêmica, no caso do judiciário, de autorreflexividade, autocorreção e autocontrole internos por causa de sua condição autoestruturada que está constituída, dinamizada e demarcada por um edificio escalonado, de instâncias justapostas e sobrepostas, caracterizadas por hierarquia processual entre câmaras de revisão sequenciais, com caráter vertical e afunilado, de baixo para cima (produção processual, com separação entre autoridade investigadora e autoridade decisória, e sua tramitação progressiva) e de cima para baixo (trâmite e decisão finais nas câmaras superiores, produção de jurisprudência e doutrina objetivas estabelecidas, de previsibilidade decisória e de similaridade de aplicação da norma), altamente dinamizadas por recurso penal e sempre direcionadas à revisão, à correção e à confirmação de sentença. Note-se, no que se refere a esse edifício sistêmico, que se trata de um trabalho sistemático, processual, instancial e publicizado com caráter gradativo, sequencial, consequencial e não-regressivo de construção, desconstrução e refundação processual, sempre demarcado, repetimos mais uma vez, tanto por hierarquia processual quanto por produção de jurisprudência doutrinal objetiva e pela coerência universal em termos de previsibilidade de aplicação da norma e de similaridade decisória, o que garante seja a consistência fundamentadora e decisória do processo (inclusive porque ele é reanalisado, revisto e corrigido ou confirmado em várias instâncias), seja a segurança, a isonomia e as mediações jurídicas estruturantes da atuação desse mesmo judiciário em termos de controle de constitucionalidade e de responsabilização jurídico-social, sempre no/como/pelo devido processo legal. O sistema judiciário, na sua relação entre direitos humanos, constituição política e direito positivo, na sua dinâmica processual com tramitação progressiva por câmaras de revisão hierárquicas, na sua centralidade do devido processo penal público-publicizado e técnico e, finalmente, na sua produção de jurisprudência objetiva, similaridade decisória e previsibilidade de aplicação da norma, consegue erradicar ao máximo perspectivas personalistas, espontaneístas e voluntaristas e, portanto, reduzir ao mínimo, quando não simplesmente eliminar, posturas antissistêmicas, anti-institucionais, antijurídicas e infralegais que politizam, partidarizam e instrumentalizam o direito, violando sua condição ontogeneticamente primária e sua autonomia, 
diferenciação e autorreferencialidade em relação à política e à moral, tornando-se, nesse caso, mero entreposto da política e da moral. Por isso mesmo, uma postura demarcada por um forte ideal de institucionalidade, legalidade, tecnicalidade, formalidade e despersonalização sistêmicas, por imparcialidade, impessoalidade e neutralidade axiológicas e por sistematicidade, processualidade, instancialidade, progressividade, mediações e publicidade, as quais são sempre afirmadas e reafirmadas, analisadas e reanalisadas em cada estrato do edifício jurídico e por cada câmara de revisão, conferem, como dizíamos acima, uma grande capacidade de o judiciário estruturar-se, legitimar-se e, então, implementar processualmente a objetividade normativo-jurídico-política ao ponto de fazer jus em sentido pleno à correlação e ao aparecimento originários de direitos humanos e direito e à condição ontogeneticamente primária, diferenciada, independente, autônoma, autossuficiente e sobreposta do direito em relação à política e à moral, exigindo, por conseguinte, só por causa dessa sua base estruturante, a subsidiariedade da política e da moral ao direito. Por outras palavras, a integridade do direito e sua completa independência em relação à política e à moral dependem pura e exclusivamente do judiciário, de seu trabalho interno ao edifício jurídico sistêmico e de sua observância estrita (a) da co-originariedade de direitos humanos e direito e da consequente separação, diferenciação, autonomia, autorreferencialidade e sobreposição do direito em relação à política e à moral, (b) da perspectiva sistêmica, sistemática, processual, mediada, instancial, progressiva e publicizada do judiciário (e, por consequência, do sistema político, a ser fiscalizado pelo judiciário), (c) da aderência estrita ao ideal de institucionalidade, legalidade, tecnicalidade, formalidade e despersonalização sistêmicas, (d) da imparcialidade, da impessoalidade e da neutralidade axiológicas e, finalmente, (e) da correta dinamização do edifício jurídico em seus estratos justapostos hierárquicos, na tramitação escalonada entre câmaras de revisão, no procedimento de revisão, correção e confirmação de sentença e, então, na produção de jurisprudência objetiva, similaridade decisória e previsibilidade de aplicação da norma, garantindo-se tanto a apoliticidadedespolitização, a tecnicalidade-logicidade e a formalidade-despersonalização desse mesmo judiciário quanto os valores democráticos da isonomia, da segurança, da simetria e da horizontalidade jurídicas, bem como a efetividade, para a existência e a realização desses valores, das mediações jurídicas estruturantes.

Nesse sentido, e esse seria o segundo ponto, se por um lado, como vimos logo acima, a integridade, a autonomia, a diferenciação, a autossubsistência e a sobreposição do direito em relação à política (formal e informal) e à moral (sempre privada) dependem de modo fundamental de que o judiciário mantenha sua integridade interna em termos desse alto ideal de institucionalidade, legalidade, tecnicalidade, formalidade e despersonalização sistêmicas, com sua apoliticidadedespolitização, impessoalidade, imparcialidade e neutralidade axiológicas, por outro é exatamente o rompimento dessa estrutura normativo-procedimental que lhe é fundadora o passo destrutivo supremo do sistema público de direito encabeçado por esse mesmo judiciário. Ou seja, a desestabilização antissistêmica e infralegal das instituições públicas e, desde elas, da sociedade civil como um todo somente pode ser realizada por meio do consentimento e até do ativismo do judiciário ou de setores dele, no sentido de uma politização, partidarização e instrumentalização voluntária do direito pela política e de uma colonização de ambos pela moral, e isso, como dissemos, primeiramente desde dentro do judiciário por operadores públicos do direito. Aqui está, em verdade, o sentido mais pungente e mais dramático da politização do direito, ou seja, a subversão pelo judiciário ou por setores dele relativamente à integridade do direito, com o solapamento de sua correlação originária aos direitos humanos e, nesse caso, de sua condição ontogeneticamente primária, separada, diferenciada, autônoma, autossuficiente e sobreposta à política e à moral, de seu ideal de institucionalidade, legalidade, tecnicalidade, formalidade e despersonalização sistêmicas e, finalmente, de sua impessoalidade, imparcialidade, neutralidade e apoliticidade-despolitização axiológicas. A politização, a partidarização e a instrumentalização do direito, nesse sentido, enquanto o fenômeno mais grave enfrentado pelas democracias contemporâneas (mais grave, inclusive, que a desigualdade socioeconômica e o racismo estrutural, especialmente para as instituições públicas, para o sistema público de direito), é causada desde dentro do judiciário, a partir do estabelecimento, da normalização e até do fomento de atitudes personalistas com caráter antissistêmico, anti-institucional, antijurídico e infralegal, as quais subvertem toda a estrutura sistêmica, sistemática, processual, instancial, progressiva, mediada e publicizada, tanto internamente a cada edifício institucional quanto no que se refere à relação, à independência, à diferenciação e à separação entre poderes, demarcada por essa correlação de ideal de institucionalidade, legalidade, tecnicalidade, formalidade e despersonalização jurídico-políticas e de imparcialidade, impessoalidade, neutralidade e apoliticidade-despolitização axiológicas. 
A partir da politização do direito no contexto do judiciário e por operadores públicos do direito, nós temos a implosão do sistema público de direito desde dentro, com sua associação, vinculação e envolvimento diretos na luta política fratricida que se desenvolve de modo incontido no contexto do sistema político entre partidos políticos, espraiando-se dali para a sociedade civil em termos de formação de uma massa-milícia digital-social de aclamação destrutiva da democracia, de modo que essa imbricação entre politização do direito desde dentro do judiciário e do sistema político e de ação antissistêmica disruptiva contra as instituições desde fora, na sociedade civil e por essa massa-milícia digital-social de aclamação, elevam o fascismo como personalismo jurídico-político antissistemico, anti-institucional, antijurídico e infralegal a uma rápida, avassaladora e fragorosa hegemonia pública, seja no âmbito das instituições, seja na esfera da sociedade civil. Como dissemos, a politização do direito desde dentro do judiciário e por seus operadores públicos constitui-se na antessala e no gesto fundador da degeneração democrática como fascismo, a qual significa, em primeiro lugar, degeneração institucional desde dentro, por parte de sujeitos institucionalizados. Sem ela, sem o rompimento voluntário da integridade do direito e da autonomia do judiciário desde dentro do próprio judiciário, não há qualquer possibilidade de o fascismo frutificar, simplesmente não há, porque, lembremos, toda a democracia pluralista e universalista como sistema público de direito está escorada e dinamizada pelo judiciário enquanto guardador e validador último da produção da universalidade na/como/pela legalidade. Por outras palavras, é por causa da politização do direito desde dentro do judiciário e por operadores públicos do direito que o fascismo contemporâneo consegue sustentar-se, legitimar-se e amplificar-se ao ponto de colonizar as instituições públicas e, uma vez hegemônico, buscar a destruição do Estado democrático de direito e o escanteamento do judiciário já iniciados pelo próprio judiciário. Nessa situação de uma degeneração personalista, voluntarista e espontaneísta do direito desde dentro e, assim, de consolidação de uma postura antissistêmica, anti-institucional, antijurídica e infralegal por operadores públicos do direito mais uma vez desde dentro do judiciário e contra ele, contra o direito e a favor da política mais rasa, temos a desestabilização, a desestruturação e a deslegitimação diretas do direito como o núcleo fundador e dinamizador da democracia e, no caso, do direito como a base estruturante, orientadora, reflexivizadora e corretora da política (formal e informal) e da moral (sempre privada); temos também, no mesmo diapasão, o próprio incentivo dado pelo judiciário ao rompimento da institucionalidade, da constitucionalidade e da legalidade da democracia, do rompimento da institucionalidade, da constitucionalidade e da legalidade como democracia, com o fomento direto do desrespeito ao direito por parte da política (formal e informal) e da moral (sempre privada).

A politização do direito, ou seja, a implosão do judiciário/direito desde dentro por operadores públicos do direito, em termos desse personalismo jurídico-político antissistêmico, antiinstitucional, antijurídico e infralegal, destrói a legitimidade do direito, a qual depende exatamente de quem mantém-protege-fomenta-realiza e de quanto e de como se mantém-protege-fomenta-realiza essa primazia ontogenética, essa diferenciação, essa separação, essa autonomia, essa independência, essa endogenia, essa autossuficiência, essa autorreferencialidade, essa autossubsistência e essa sobreposição do direito em relação à política e à moral - bem como, consentaneamente, de que a política (formal e informal) e a moral (sempre privada) sejam permanentemente subsidiárias do direito, estando fundadas na universalidade dos direitos humanos e traduzidas completamente ao direito positivo. Essa é a condição-relação-base-princípio estruturante da democracia e nela se ancora, se desenvolve, se dinamiza e se legitima todo o sistema público do direito, começando pelo judiciário como sua pedra angular, passando pelo sistema político (na correlação de legislativo bicameral e de executivo), ramificando-se à sociedade civil e chegando-se à centralidade e à integridade do devido processo legal e das mediações jurídico-institucionais estruturantes demarcadoras da produção autorreflexiva, autocontrolada e autocorretiva da universalidade na/como/pela legalidade. Esse quem, esse quanto e esse como se mantém, fomenta, protege e realiza a integridade do direito aponta diretamente para o judiciário, tem ao judiciário como seu destinatário mais básico. Por isso mesmo, se há essa autoimplosão do judiciário e do direito internamente ao próprio judiciário em termos desse personalismo antissistêmico, anti-institucional, antijurídico e infralegal, então, como já dizíamos em nossa remodelação do dito de Ivan Karamazov, tudo o mais está permitido. Com efeito, nesse contexto, de uma autoimplosão interna do judiciário/direito por seus próprios operadores, nós temos a concessão direta de uma carta branca a sujeitos-grupos fascistas no contexto do sistema político e do âmbito da sociedade civil a assumirem tal atuação antissistêmica, anti-institucional, antijurídica e infralegal internamente ao sistema político e, desde ele, em profunda intersecção com essa massamilícia digital-social de aclamação construída e emergente na sociedade civil, desde a sociedade civil e direcionada a um ataque destrutivo intenso contra o sistema público de direito de um modo geral e 
contra o judiciário em particular - em muitas situações contra o próprio legislativo.

É por isso que, no nosso entender, a politização do direito é um fenômeno do judiciário $e$ causado pelo judiciário desde dentro, enquanto autoimplosão antissistêmica interna, por seus operadores públicos, e não pelo sistema político e pelos partidos políticos. Obviamente, partidos e lideranças políticas, de modo corriqueiro e normalizado, embora principalmente a partir do contexto do impeachment de Dilma Rousseff e das crises políticas enfrentadas por Michel Temer, buscaram ardorosamente instrumentalizar o direito com fins político-partidários, como arma dessa guerra político-partidária autofágica (lembremos de gestos emblemáticos por lideranças políticas da época, que coordenaram o impeachment, como: "acordão com Supremo, com tudo", do então senador Romero Jucá; “Tem de manter isso aí, viu!", do então presidente Michel Temer a Joesley Batista e referindo-se ao ex-deputado Eduardo Cunha, um dos artífices mais centrais do impeachment). Mas o grosso do protagonismo, no que se refere à politização, à partidarização e à instrumentalização do direito, se deveu ao próprio judiciário, a setores específicos dele, a operadores públicos do direito militantes, como é o caso da Operação Lava-Jato em torno ao processo penal contra Lula e sua vinculação posterior a Jair Messias Bolsonaro, pelo menos no que se refere ao exemplo específico do na época juiz federal Sergio Fernando Moro (que, aliás, também deu o golpe de morte em Dilma Rousseff, com a divulgação parcial e seletiva - e ilegítima - de áudios envolvendo conversa entre Dilma Rousseff e Luís Inácio Lula da Silva), conforme ampla revelação relativa a todas estas situações (lembremos, ainda, nesse caso, de falas como "Nossa capacidade institucional de limpar o congresso", de Sergio Fernando Moro a Deltan Dallagnol; "Melindra alguém cujo apoio é importante", mais uma vez de Sergio Fernando Moro a Deltan Dallagnol, o qual responde que "Foi para passar uma imagem de imparcialidade" por parte da Operação Lava-Jato; "Seus sinais conduzirão multidões", agora de Deltan Dallagnol a Sergio Fernando Moro etc.). Enfatize-se, mais uma vez, esta nossa afirmação: a politização, a partidarização e a instrumentalização do direito é um fenômeno próprio ao judiciário e à sua subversão interna, em termos de personalismo jurídico-político antissistêmico, anti-institucional, antijurídico e infralegal, o qual destrói a separação, a diferenciação, a autonomia, a autorreferencialidade e sobreposição do direito em relação à política e à moral, subvertendo essa lógica estrutural básica à democracia, de modo a tornar o direito em subsidiário à política e à moral e, na verdade, destruindo sua primariedade ontogenética, além de, por consequência, seja o ideal sistêmico de institucionalidade, legalidade, tecnicalidade, formalidade e despersonalização, seja a dinâmica sistemática, processual, mediada, instancial, progressiva e publicizada do trabalho de produção da objetividade normativo-jurídico-política, seja, finalmente, a perspectiva imparcial, impessoal, neutra e apolítico-despolitizada em termos axiológicos, pilares fundamentais para a integridade do direito/judiciário, para sua capacidade de estabilizar-se e legitimar-se e, consentaneamente, de enquadrar, reflexivizar, corrigir e controlar o sistema político e a sociedade civil, atuando de modo contramajoritário em relação a eles - e inclusive obrigando o próprio sistema político a agir de modo contramajoritário.

A democracia pluralista e universalista é direito, sistema público de direito, e só depois política e moral. E é o judiciário a instituição guardadora dessa condição fundacional, estruturante, legitimadora e dinamizadora da democracia. Ora, ele somente pode fazer e cumprir esta tarefa, a qual lhe permite estabilizar-se e legitimar-se internamente e, depois, frente ao sistema político e à sociedade civil, por meio da satisfação plena destes quatro pilares acima, a saber, repetimos: (a) correlação originária e aparecimento concomitante de direitos humanos e direito, que permite a separação, a diferenciação, a primariedade ontogenética, a autonomia, a autorreferencialidade e a sobreposição do direito em relação à política e à moral; (b) o forte ideal de institucionalidade, legalidade, tecnicalidade, formalidade e despersonalização sistêmicas; (c) a dinâmica sistemática, processual, mediada, instancial, progressiva e publicizada de produção da objetividade normativo-jurídico-política; e (d) a perspectiva sistêmico-institucional de imparcialidade, neutralidade, impessoalidade e apoliticidadedespolitização axiológicas. A politização e a partidarização do direito/judiciário desde dentro do próprio judiciário, internamente ao próprio judiciário, rompe com estes pressupostos, uma vez que somente é possível pelo solapamento e pela violação deles. Porém, isso não é feito sem que se pague o alto preço da desestabilização, da desestruturação e da deslegitimação do direito e do judiciário como respectivamente o código normativo objetivo e a instituição validadora da democracia pluralista e universalista como um todo. A efetividade da democracia como um todo, portanto, repousa direta e pungentemente no fato de que o judiciário possa assumir, proteger, fomentar e realizar internamente esses quatro pilares constitutivos, dinamizadores e legitimadores do sistema público de direito, os quais são toda a condição de legitimidade para a própria constituição, atuação e vinculação públicoinstitucional do judiciário e para $\mathrm{a}$ - e garantidores da - centralidade do direito em relação à política e 
à moral, bem como da subsidiariedade destas em relação àquele. É por isso que, enquanto postura específica do judiciário internamente a si e em termos de ataque aos quatro pilares acima, a politização, a partidarização e a instrumentalização do direito geram isso que chamamos, ao longo do texto, de personalismo jurídico-político antissistêmico, anti-institucional, antijurídico e infralegal, o qual, ao implodir o direito como base normativa e violar a estrutura sistêmica do judiciário e seu ideal de institucionalidade, legalidade, tecnicalidade, formalidade e despersonalização, abre a porteira do fascismo que é, em primeira mão, também um movimento antissistêmico regressivo demarcado pelo personalismo autocrático que rompe com o direito, com as mediações jurídicas, com o devido processo legal e com a diferenciação, a separação e a sobreposição de poderes, apagando a isonomia, a segurança, a simetria e a horizontalidade jurídicas que, garantidas pelo judiciário em termos de integridade interna (do edifício jurídico) e externa (a sua relação com o sistema político e a sociedade civil) e sob a forma da centralidade do direito, refreiam o próprio fascismo. Mas os sujeitos-grupos fascistas só conseguem hegemonia, repetimos mais uma vez, porque já houve degeneração ampla do sistema judiciário e, nesse caso, fragilização intensa do direito, ao ponto de consolidarmos não apenas a inação institucional e a desvirtuação da independência e da sobreposição entre poderes, mas também a normalização da violação da isonomia, da segurança, da simetria, da horizontalidade e das mediações jurídicas. A partir de então, o golpismo permanente e a tendência a uma regressão totalizante adentram no próprio coração das instituições públicas e de lá não sairão tão facilmente, fragilizando-as permanentemente.

Em contrapartida, a judicialização da política é um fenômeno que demarca a relação entre sociedade civil e sistema político, sistema político e sociedade civil, relação essa mediada, físcalizada e orientada pelo judiciário e fundada na universalidade dos direitos humanos (como a única, exclusiva, suficiente e necessária base normativa da democracia como um todo, de suas instituições públicas e do direito), traduzida ao procedimentalismo, à principialidade, à simbologia e à linguagem do direito positivo, centralizada pelo devido processo legal público-publicizado como o único instrumento seja para a manifestação público-institucional (das instituições e da esfera pública, dos sujeitos formais e dos sujeitos informais), seja para a produção da objetividade normativo-jurídico-política, e dinamizada - no caso da relação dialética entre sociedade civil, sistema político e judiciário - pela existência e pelo efetivo funcionamento de canais oficiais de contato e de interação dos sujeitos sociopolíticos e da opinião pública relativamente aos sistemas sociais direito e política (conselhos, corregedorias, ouvidorias, representantes legais e mesmo referendos, plebiscitos, assembleias nacionais constituintes e projetos de lei de autoria popular, complementares às eleições regulares, à vinculação partidária, à participação em movimentos sociais e iniciativas cidadãs e à possibilidade de implementação de processo jurídico e de recurso penal, bem como à existência de esferas institucionais fiscalizadoras do próprio trabalho realizado no sistema político, na administração pública e no judiciário, como os TCUs, o MPF, os MPEs etc. - como se vê, a democracia enquanto geradora e viabilizadora de enormes possibilidades de interação sociopolítica com as instituições e de autorreflexividade, autocorreção e autocontrole sistêmicos, tanto internamente às instituições e entre instituições quanto nessa relacionalidade e intersecção com a sociedade civil e a opinião pública via canais institucionais oficiais de contato e de interação!).

A judicialização da política é, como se pode perceber, uma consequência institucional, social e normativa direta e necessária do fato de que a democracia pluralista e universalista é, antes de tudo e como condição para tudo o mais, direito, e só depois política e moral; de que a democracia é um sistema público de direito destinado à materialização dos direitos humanos sob a forma de universalização dos direitos e das garantias fundamentais e da efetivação da isonomia, da segurança, da simetria, da horizontalidade e das mediações jurídicas estruturantes para todos e para cada um dos sujeitos sociopolíticos enquanto sujeitos de e a direitos, de modo incondicional, irrestrito, inultrapassável e inviolável, primeiramente por meio do compartilhamento de tarefas entre judiciário, que realiza controle de constitucionalidade e responsabilização jurídico-social, e sistema político que, na correlação, diferenciação e sobreposição de legislativo bicameral e de executivo, assume a tarefa de produção de políticas públicas, de previsão constitucional e de principialidade jurídica. Em segundo lugar, a materialização dos direitos humanos na correlação e na sobreposição de judiciário e sistema político implica exatamente na centralidade desse sistema público de direito que, a partir dos direitos humanos como sua base fundadora, se ramifica em constituição política e direito positivo, em judiciário independente e íntegro, diferenciado, separado, autônomo, autorreferencial, autossubsistente e sobreposto ao sistema político, na centralidade do devido processo legal público-publicizado, na condição basilar seja da perspectiva sistêmica, sistemática, processual, mediada, instancial, progressiva e publicizada, seja do forte ideal de institucionalidade, legalidade, tecnicalidade, formalidade e 
despersonalização metodológico-procedimentais, seja da inultrapassável e fundacional postura axiológica imparcial, impessoal, neutra e apolítico-despolitizada em termos da produção institucional da objetividade normativo-jurídico-política. Como se percebe, as instituições como um todo e o sistema político em particular (já que a judicialização da política, como dissemos acima, se refere à relação entre sociedade civil, com suas demandas normativas e sua pluralidade sociopolítica, e sistema político com sua disputa partidária em torno a projetos administrativos e ao poder estatal, mediada, orientada e validada pelo judiciário) têm de fundar-se na universalidade dos direitos humanos e materializá-la em sua radicalidade e, para isso, precisam traduzir-se completamente ao procedimentalismo, à principialidade, à simbologia e à linguagem do direito positivo, assumindo essa postura sistêmica, legal e técnica, sem qualquer outra possibilidade, inclusive a fim de se evitar o personalismo jurídico-político antissistêmico, anti-institucional, antijurídico e infralegal.

Por isso mesmo, a judicialização da política é, no nosso modo de entender, uma das características mais determinantes da pujança da democracia em termos de equalização e integração formais e materiais da pluralidade sociopolítica e de seus anseios normativos, em muitos casos denegados ou violados pelo sistema político e pela administração pública, e de centralidade, dinamização e maturidade de seu sistema público de direito, o qual controla e orienta essa mesma administração pública e sua ramificação em sistema político. Ela não pode ser entendida como um sinônimo de intromissão entre poderes e sequer como representando a falta de maturidade da cultura democrática relativamente a um consenso político mínimo em torno a direitos e a garantias fundamentais (isto é, neste último caso, como a sociedade civil e o sistema político não conseguem resolver seus problemas básicos, apela-se ao judiciário; como os sujeitos sociopolíticos e pertencentes ao sistema político não se respeitam mutuamente, apelam ao direito para travar a política - essa imaturidade democrática ou esse jogo sujo dos partidos políticos tem no medium do direito e na mediação do judiciário seu núcleo reflexivizador e controlador); e sequer esse protagonismo do judiciário em relação ao sistema político pode ser entendido negativamente, como impondo tanto ao sistema político quanto à sociedade civil posturas, comportamentos e valores que estes se recusam em um primeiro momento a assumir, a institucionalizar e a implementar de modo vinculante, porque o judiciário é o guardião da universalidade dos direitos humanos e, nesse caso, tem de validar ou invalidar, de impor, exigir, orientar e definir como, de que modo, quando, quanto e por quem a objetividade normativo-jurídico-política deve ser implantada - por outras palavras, o judiciário, na medida em que é forma e conteúdo (porque os direitos humanos, que constituem o sistema público de direito, são forma e conteúdo), tem de necessariamente impor uma orientação positiva, e não meramente negativa, ao sistema político e à sociedade civil.

A orientação negativa imposta pelo sistema judiciário ao sistema político e à sociedade civil diz respeito à proteção penal e proibitória de toda e qualquer medida e/ou postura, assumida por lideranças e partidos políticos institucionalizados e pertencentes ao sistema político e por grupossujeitos informais sediados na sociedade civil (geralmente interseccionados) que tendam a violar, que incentivem a violar e, finalmente, que neguem, deslegitimem e ponham em perigo os direitos e as garantias fundamentais e a isonomia, a segurança, a simetria, a horizontalidade e as mediações jurídicas estruturantes, sem as quais não pode haver democracia - ademais de exigir exatamente a tradução ao direito positivo e a sua manifestação no/como/pelo devido processo legal, a autolimitação e a moderação institucionais e, então, a efetividade de ritos institucionais, de prazos regimentais e da forma de produção, legitimação, decisão, tramitação e implementação processuais, de similaridade decisória e de previsibilidade de aplicação e de vinculação da administração pública à pluralidade sociopolítica. Nesse quesito de uma orientação negativa no que tange à relação entre sociedade civil e sistema político embasada na universalidade dos direitos humanos, mediada pelo direito e fiscalizada, gerida, orientada e validada ou invalidada pelo judiciário, a judicialização do trabalho interno e da vinculação social e pública desse mesmo sistema político, a partir do acionamento do judiciário seja por sujeitos institucionalizados (partidos e lideranças políticos e instituições públicas de controle, incluindo-se representantes legais da sociedade civil, reconhecidos institucionalmente, como a Ordem dos Advogados do Brasil), seja também por sujeitos não-institucionalizados pertencentes à sociedade civil (os quais, para acionarem o judiciário, precisarão assumir a forma jurídica, o devido processo legal e a tradução ao direito, obviamente), é fundamental para evitar-se que, sob o falso argumento da "vontade das maiorias" ou da equivocada submissão do direito e da política à moral tentada por sujeitos-grupos fascistas, racistas e fundamentalistas (com a consequente politização do direito e a messianização da política), lideranças públicas, agentes administrativos e partidos políticos subvertam as instituições, solapem o devido processo legal e a diferenciação, a separação e a sobreposição entre poderes e, finalmente, arrasem com as mediações jurídicas estruturantes, negando o pluralismo- 
diversidade e a universalidade dos direitos humanos - além de tentarem, obviamente, implodir o judiciário e o legislativo (no caso do executivo) ou o judiciário e o executivo (no caso do legislativo). $\mathrm{O}$ acionamento do judiciário para avaliar violações institucionais dos direitos humanos e do pluralismo-diversidade, da integridade do sistema público de direito e, então, da atuação do sistema político desde a condição ontogeneticamente primária e sobreposta do direito em relação à política e à moral e à consequente subsidiariedade destas frente àquele é a possibilidade primeira e última à democracia, sua condição estrutural, aliás, quando a negociação, a representação e o contraponto político-partidários, a pressão e a fiscalização da opinião pública e a participação social ampliada não forem suficientes para refrear tendências fascistas, totalitárias, fundamentalistas e racistas disruptivas do sistema público de direito de um modo geral e desestabilizadoras e deturpadoras do sistema político em particular. A orientação negativa imposta pelo judiciário ao sistema político em seu relacionamento com a sociedade civil é o primeiro ponto da judicialização da política como caudatária dessa diferenciação, separação, autonomia, autorreferencialidade, autossubsistência e sobreposição do direito em relação à política e à moral e, por conseguinte, do judiciário e do sistema político, que leva (a) à correlação de direitos humanos e direito como base normativa fundacional, legitimadora e dinamizadora da democracia pluralista e universalista e de seu sistema público de direito, (b) ao forte ideal sistêmico de institucionalidade, legalidade, tecnicalidade, formalidade e despersonalização, (c) à perspectiva sistemática, processual, mediada, instancial, progressiva e publicizada do trabalho do judiciário e do sistema político, de sua intersecção, separação e sobreposição, e (d) à postura axiológica de neutralidade, imparcialidade, impessoalidade e apoliticidade-despolitização institucionais.

A orientação positiva imposta pelo judiciário ao sistema político em sua tematização dos sujeitos, das demandas e dos déficits sociais e reivindicadas por esses diferentes grupos-sujeitos sociais enquanto uma exigência democrática básica tanto ao sistema político quanto, quando ele não as realiza, ao próprio sistema judiciário constitui-se no segundo ponto desse fenômeno da judicialização da política enquanto característica e caminho de constituição do sistema público e democrático de direito e, nesse caso, seja da vinculação do sistema político à pluralidade própria à sociedade civil, seja de participação dessa mesma pluralidade no sistema político, seja, finalmente, do trabalho assumido pelo judiciário em termos de controle de constitucionalidade e de responsabilização jurídico-social frente ao sistema político e à sociedade civil. Com efeito, no caso dessa orientação positiva imposta pelo judiciário ao sistema político, não estamos mais no âmbito da proibição de que a administração pública e o sistema político produzam atos, realizem procedimentos e fomentem valores fascistas, totalitários, fundamentalistas e racistas, que se abstenham de violações aos direitos e às garantias fundamentais, ao devido processo legal, à separação, à diferenciação e à sobreposição entre poderes e mesmo no que se refere a evitar-se o solapamento da neutralidade, imparcialidade, impessoalidade e formalidade institucionais. Nós adentramos, agora, na obrigação de fazer, na orientação e na determinação de que o poder político e a administração pública produzam políticas públicas, previsão constitucional e principialidade jurídica, ou que simplesmente resolvam problemas de integração social que são efetivamente da alçada e da responsabilidade das administrações públicas, do sistema político. Lembremo-nos de que falamos, ao longo desse texto, que o sistema público de direito se constitui enquanto tendo por base normativa a correlação originária entre direitos humanos e direito, $o$ que confere uma condição ontogeneticamente primária, separada, diferenciada, autônoma, independente, endógena, autorreferencial, autossubsistente, autossuficiente e sobreposta do direito em relação à política e à moral, com a consequente subsidiariedade da política e da moral ao direito, o que implica, neste caso da subsidiariedade, na completa fundação da política e da moral ao direito e na sua tradução plena ao procedimentalismo, à principialidade, à simbologia e à linguagem do direito positivo. No mesmo diapasão, o sistema público de direito se divide em judiciário e sistema político, os quais têm por meta o trabalho compartilhado no que tange à materialização dos direitos humanos, de modo que o judiciário se responsabiliza por controle de constitucionalidade e responsabilização jurídico-social e o sistema político tem por meta a produção de políticas públicas, de previsão constitucional e de principialidade jurídica, obviamente sempre a partir da independência, da autorreferencialidade e da sobreposição do judiciário em relação ao sistema político, ademais de ambos os sistemas sociais sempre atuando de modo contramajoritário e se manifestando pública e administrativamente e produzindo objetividade normativo-jurídico-política sempre e apenas no/como/pelo devido processo legal público-publicizado.

Note-se, pela definição acima relativamente ao sistema público de direito próprio à democracia pluralista e universalista, que o judiciário constitui-se como a instituição estruturante e como a pedra angular de validação da democracia como um todo e de suas instituições em particular, 
na medida em que, por meio do controle de constitucionalidade e da responsabilização jurídico-social, ele tem, entre outras coisas, de fiscalizar, enquadrar, reflexivizar, controlar e gerir o sistema político, validando ou invalidando o que se faz no sistema político, sempre que acionado. Nesse sentido, a orientação positiva do sistema político por parte do judiciário é algo consequente e necessário à condição do sistema público de direito próprio à democracia pluralista e universalista, servindo, na verdade, para que a democracia possa ser protegida em sua tríade normativa e constitutiva básica, o pluralismo-diversidade, os direitos humanos e o Estado democrático de direito (tríade essa absolutamente imbricada e mutuamente dependente, uma não existindo sem a outra). O judiciário, assim, pode obrigar o sistema político a fazer, sempre que esse mesmo sistema político está desestruturado, desestabilizado e desvirtuado por confrontos político-partidários fratricidas, por corrupção política, por conflitos na relação entre legislativo e executivo (na medida em que, nesse caso, tal conflito leva a sabotagens antidemocráticas, ilegais e infralegais, em termos de travamento dos processos de reconhecimento, inclusão, participação e integração institucionalizados e implementados sob a forma de políticas públicas e de gestão político-administrativa da sociedade). Essa atitude e essa responsabilidade próprias ao judiciário de obrigar o sistema político a fazer, isto é, essa orientação positiva do sistema político por parte do judiciário, aliás, é totalmente consentânea à sua atitude e à sua responsabilidade de obrigar o poder político a não fazer ou a desfazer atos considerados lesivos aos direitos e às garantias fundamentais, à separação entre direito, política e moral, à neutralidade institucional. E o judiciário simplesmente não pode se furtar a isso, porque no limite o controle de constitucionalidade e a responsabilização jurídico-social, que the são tarefas e atributos básicos, exigem que o sistema jurídico - inclusive por causa de seu enorme potencial administrativo, gerencial e estruturante que lhe é conferido pelo Estado democrático de direito em sua carta constitucional, em seu sistema de direito positivo e no que tange à utilização técnica de contribuições científicas multidisciplinares (isso sem se falar no sólido conjunto da literatura jurídica desenvolvida em torno à condição, ao trabalho e à orientação do judiciário, uma vasta, riquíssima e maturada literatura jurídica, assim como na jurisprudência doutrinal produzida no contexto das câmaras superiores) - o impelem, lhe conclamam a um enquadramento processual e a um papel mediador e validador relativamente a tudo o que se faz politicamente, à dialética própria à disputa partidária e à relacionalidade entre legislativo e executivo. Aliás, a perspectiva do controle de constitucionalidade está diretamente ligada e direcionada ao enquadramento, à reflexivização, à correção e ao controle do sistema político, de sua atuação interna e de sua vinculação seja com a sociedade civil, seja como o próprio judiciário. Enquanto tal, como estamos argumentando, não há como fugir a essa responsabilidade básica que coloca o judiciário como a instituição guardadora e como a pedra angular de validação da democracia pluralista e universalista constituída enquanto um sistema público de direito, situação que obriga o judiciário (a) a fundar-se na universalidade dos direitos humanos, a assumir a condição ontogeneticamente primária, separada, diferenciada, autônoma, independente, endógena, autorreferencial, autossubsistente, autossuficiente e sobreposta do direito frente à política e à moral e a traduzir-se completamente ao direito positivo; (b) a efetivar um forte ideal de institucionalidade, legalidade, tecnicalidade, formalidade e despersonalização sistêmicas; (c) a assumir uma dinâmica sistemática, processual, mediada, instancial, progressiva e publicizada em termos de produção da objetividade normativo-jurídico-política; e (d) a agir axiologicamente de modo imparcial, impessoal, neutro e apolítico-despolitizado. Por isso, inclusive, que falamos, ao longo do texto, de que esses quatro princípios estruturantes do sistema público de direito democrático precisam ser assumidos, fomentados, protegidos e realizados pelo judiciário em primeira mão, dada sua centralidade na democracia pluralista e universalista e frente ao sistema político e à sociedade civil. Tais princípios estruturantes, uma vez assumidos em cheio pelo judiciário, lhe conferem legitimidade inconteste em seu trabalho de controle de constitucionalidade relativamente ao sistema político e sob a forma de orientação positiva deste em torno ao fazer, ao implantar a materialização dos direitos humanos e de orientação negativa no que se refere ao abster-se de realizar atitudes violadoras dos direitos humanos, do pluralismo, do Estado democrático de direito, do devido processo legal e da separação, da diferenciação e da sobreposição entre poderes.

Por isso mesmo, a judicialização da política não pode ser entendida como algo negativo e problemático à democracia e, no caso, como intromissão do judiciário no sistema político e em matérias, atos e processos de justificação que são exclusivos do sistema político. Ora, não há nada que seja específico da sociedade democrática, incluindo-se aqui o sistema político, que não seja objeto de fiscalização e de validação do judiciário, por parte do judiciário. Simplesmente nada, principalmente quando nos referimos às instituições, aos sujeitos, aos atos e procedimentos, aos valores e aos símbolos públicos, os quais definem, às vezes de modo indelével e não-passível de correção, os 
processos de socialização e subjetivação. Porque, como estamos argumentando, o controle de constitucionalidade e a responsabilização jurídico-social sobre o sistema político não podem ser realizados pelo próprio sistema político sobre si mesmo, pelos partidos políticos entre si e sobre si mesmos, pelos grupos sociopolíticos e pela opinião pública por si, entre si e sobre si mesmos. Pelo menos não em sentido último, posto que essa postura de construção e de validação última (isto é, produção instancial, progressiva, mediada, processual) da objetividade normativo-jurídico-política somente pode ser realizada pelo judiciário, desde dentro dele e a partir do devido processo legal, com sua tramitação em estratos escalonados e justapostos demarcados por câmaras de revisão hierarquicamente constituídas e direcionadas à revisão, à correção e à confirmação de sentença, além de dinamizadas por jurisprudência doutrinal objetiva, similaridade decisória e previsibilidade de aplicação da norma. Nesse caso, tudo o que é feito no sistema político, internamente a ele, sob a forma do devido processo legal, por seus sujeitos institucionalizados e desde a separação, a diferenciação, a interrelação e a sobreposição do legislativo bicameral em relação ao executivo, é objeto de consideração, de enquadramento, de reflexivização, de controle, de correção e de validação legal por parte do judiciário e, por isso mesmo, o sistema político não só precisa aprender a - e querer ardorosamente - fundar-se na universalidade dos direitos humanos, a afirmar a centralidade do pluralismo, a traduzir-se na linguagem do direito, a manifestar-se exclusivamente pelo instrumento do devido processo legal e, finalmente, a estruturar-se em concordância às condições, aos princípios estruturantes, às exigências e à dinâmica do Estado democrático de direito, como também necessita entender que ele (o próprio sistema político) está direcionado à materialização dos direitos humanos como sua tarefa básica, exclusiva, suficiente e necessária e de que, para isso, a primazia e a sobreposição do direito em relação à política e à moral lhe são obrigatórias, assim como, por consequência, o controle de constitucionalidade e a responsabilização jurídico-social por parte de um judiciário independente, íntegro (no sentido dos quatro princípios estruturantes acima delimitados) e sobreposto ao sistema político são fundacionais para o judiciário e são o fecho de abóboda último (sob responsabilidade do judiciário, como prerrogativa do judiciário) do próprio sistema político na separação e na sobreposição do legislativo bicameral em relação ao executivo e em termos do multipartidarismo político, com seus confrontos, alianças, mediações, sínteses e acordos. Ora, se o sistema político não cumpre e não respeita esses princípios estruturantes da democracia, então ele será exatamente enquadrado, reflexivizado, gerido, orientado, corrigido, controlado e responsabilizado pelo sistema jurídico, uma questão simplesmente caudatária da própria ideia de uma democracia pluralista e universalista constituída enquanto um sistema público de direito altamente institucionalista, legalista, tecnicista, formalista e despersonalizado, demarcado seja por sistematicidade, processualidade, mediações, instancialidade, progressividade e publicidade, seja por imparcialidade, impessoalidade, neutralidade e apoliticidade-despolitização axiológicas - uma democracia que, conforme estamos afirmando, é direito antes de tudo e como condição para tudo o mais, sendo fundada na separação, na diferenciação, na autonomia, na autossubsistência e na sobreposição do direito em relação à política e à moral e estando materializada sob a forma de um sistema público de direito autoestruturado processualmente, na interrelação, na autonomia, na autorreferencialidade e na sobreposição do judiciário em relação ao sistema político.

\section{CONSIDERAÇÕES FINAIS}

A judicialização da política e a politização do direito são, respectivamente, a postura institucional mais basilar e a atitude sistêmica mais disruptiva e destrutiva à democracia pluralista $\mathrm{e}$ universalista constituída como um sistema público de direito, representando, na verdade, todo o potencial, toda a condição dessa mesma democracia pluralista e universalista de cunho pós-tradicional, não-etnocêntrica e não-egocêntrica constituída enquanto um sistema público de direito (no caso da judicialização da política), ou a sua abertura e a sua liberação do caos sociopolítico e da desestabilização institucional aguda, ou seja, da liberação e do fomento do fascismo enquanto personalismo jurídico-político antissistêmico, anti-institucional, antijurídico e infralegal (no caso da politização do direito). Essa mesma democracia pluralista e universalista constituída como um sistema público de direito é demarcada pela e direcionada à produção autorreflexiva, autocontrolada e autocorretiva da universalidade na/como/pela legalidade, e isso implica em algumas condições fundamentais para sua estruturação, legitimação, estabilização e dinamização ao longo do tempo enquanto sociedade-cultura-institucionalidade-normatividade-consciência antifascista, antitotalitária, não-fundamentalista e antirracista, a saber: (a) a correlação originária e o aparecimento concomitante 
de direitos humanos e direito, o que confere primazia ontogenética, diferenciação, separação, independência, autonomia, endogenia, autorreferencialidade, autossuficiência, autossubsistência e sobreposição do direito em relação à política e à moral, com a subsidiariedades destas em relação àqueles; (b) consentaneamente, a separação, a diferenciação, a autonomia, a autorreferencialidade e a sobreposição do judiciário em relação ao sistema político e à sociedade civil, os quais são obrigados a fundarem-se de modo pleno na universalidade dos direitos humanos e a traduzirem-se completamente no procedimentalismo, na principialidade, na simbologia e na linguagem do direito positivo; (c) uma perspectiva organizacional e de funcionamento tanto ao judiciário quanto ao sistema político (inclusive em termos de sua relacionalidade) altamente sistêmica, sistemática, processual, mediada, instancial, progressiva e publicizada direcionada à produção da objetividade normativo-jurídico-política, isto é, à materialização dos direitos humanos, através do compartilhamento de tarefas entre judiciário (controle de constitucionalidade e responsabilização jurídico-social) e sistema político (produção de políticas públicas, de previsão constitucional e de principialidade jurídica), ambos atuando de modo contramajoritário e sob a forma do devido processo legal; (d) o forte ideal de institucionalidade, legalidade, tecnicalidade, formalidade e despersonalização procedimental-metodológico necessário ao judiciário e ao sistema político; e (e) a postura institucional imparcial, impessoal, neutra e apolíticodespolitizada em termos axiológicos.

É nesse sentido, primeiramente, que a produção da universalidade na/como/pela legalidade, isto é, a materialização da universalidade dos direitos humanos em direito e garantias fundamentais, atribuídos incondicional e irrestritamente a todos e a cada um dos sujeitos sociopolíticos enquanto sujeitos de direito e sujeitos a direitos, e a efetivação de sua segurança, de sua isonomia, de sua simetria e de sua horizontalidade jurídicas implicam não só na satisfação de mediações jurídicas estruturantes através da consecução destes seis princípios basilares à democracia pluralista e universalista constituída como e por um sistema público de direito, mas também em uma atitude de protagonismo do judiciário que, mantendo seu forte ideal de institucionalidade, legalidade, tecnicalidade, formalidade e despersonalização e protegendo e afirmando a separação, a autonomia, a autorreferencialidade e a sobreposição do judiciário em relação ao sistema político (e, portanto, do direito em relação à política e à moral), instaura uma perspectiva de enquadramento, de reflexivização, de correção, de controle e de reorientação do sistema político (e da sociedade civil) demarcada tanto por uma orientação positiva quanto por uma orientação negativa, de modo a obrigar o sistema político a também fundar-se de modo estrito nestes seis princípios estruturantes acima delimitados e constitutivos em sentido fundacional da democracia pluralista e universalista autoestabelecida como um sistema público de direito. Note-se, nesse sentido, que nossa afirmação de que a estabilização ou a desestabilização de uma sociedade começa e na verdade, é realizada pelo judiciário, conforme desenvolvemos ao longo do texto, retorna com toda a força em nossas conclusões finais, apontando para o fato de que a produção autorreflexiva, autocontrolada e autocorretiva da universalidade na/como/pela legalidade tem na centralidade do direito, do judiciário, do devido processo legal e da separação, autonomia e sobreposição de poderes seu núcleo estrutural e sua dinâmica mais básica, de modo que, aqui, o direito orienta a política e a moral e o judiciário valida ou invalida, sempre que acionado, o sistema político e a sociedade civil, obrigando-os não só a fundarem-se na universalidade dos direitos humanos e a traduzirem-se ao direito positivo em termos de sua legitimidade interna (a cada posição político-moral) e externa (sua vinculação público-institucional), mas também a assumirem o forte ideal de institucionalidade, legalidade, tecnicalidade, formalidade $\mathrm{e}$ despersonalização procedimental-metodológicas e a postura de imparcialidade, impessoalidade, neutralidade e apoliticidade-despolitização axiológicas. Obviamente, essa condição fundacional, constitutiva, estruturante e dinamizadora da democracia pluralista e universalista constituída como um Estado democrático de direito direcionado à materialização dos direitos humanos e ao fomento do pluralismo em termos de produção da universalidade na/como/pela legalidade precisa ser assumida, fomentada, protegida e realizada, antes de tudo e como condição para tudo o mais, pelo judiciário internamente a si mesmo, em seu edifício sistêmico instancial, estratificado, justaposto e hierárquico, na progressividade de suas câmaras de revisão e na centralidade do devido processo legal, e em sua relação com o sistema político, a qual, neste caso, precisa ser demarcada pela autonomia, pela separação, pela diferenciação, pela integridade e pela sobreposição do judiciário ao sistema político e, assim, do direito em relação à política e à moral. Ora, nesse quadro interpretativo e normativo amplo que desenvolvemos ao longo do texto podemos, por um lado, entender o sentido, a dinâmica e as condições fundacionais, estruturantes e dinamizadoras da democracia pluralista constituída enquanto um sistema público de direito e algumas das razões pelas quais o fascismo pode emergir e se tornar hegemônico no sistema político e na sociedade civil democráticos, implodindo o sistema público de 
direito desde dentro das instituições públicas (e por meio da subversão destas) para fora. E, em ambas as situações, o que pudemos perceber é que tudo dependerá, na democracia, da centralidade do direito e do judiciário, do protagonismo do direito e do judiciário (inclusive o fascismo como personalismo jurídico-político antissistêmico, anti-institucional, antijurídico e infralegal, do qual o judiciário precisa se precaver urgentemente, erradicando-o de dentro de seu sistema de direito e por meio da correta orientação deste nos seis princípios estruturantes acima delimitados).

\section{REFERÊNCIAS}

CATROGA, Fernando. Entre deuses e césares: secularização, laicidade e religião civil - uma perspectiva histórica. Coimbra: Edições Almedina, 2006.

CÉSAIRE, Aimé. Discurso sobre o colonialismo. Lisboa: Livraria Sá da Consta Editora, 1978.

FANON, Frantz. Os condenados da Terra. Rio de Janeiro: Paz e Terra, 1968.

FANON, Frantz. Pele negra, máscaras brancas. Salvador: Editora da UFBA, 2008.

FERNANDES, Florestan. A integração do negro na sociedade de classes. São Paulo: Global, 2008.

FORST, Rainer. Contextos da justiça: filosofia política para além de liberalismo e comunitarismo. São Paulo: Boitempo, 2010.

HABERMAS, Jürgen. Teoria do agir comunicativo (Vo. I): racionalidade da ação e racionalização social. São Paulo: Martins Fontes, 2012a.

HABERMAS, Jürgen. Teoria do agir comunicativo (Vol. II): sobre a crítica da razão funcionalista. São Paulo: Martins Fontes, 2012b.

HABERMAS, Jürgen. Direito e democracia: entre facticidade e validade (Vol. I). Rio de Janeiro: Tempo Brasileiro, 2003a.

HABERMAS, Jürgen. Direito e democracia: entre facticidade e validade (Vol. II). Rio de Janeiro: Tempo Brasileiro, 2003b.

HABERMAS, Jürgen. A inclusão do outro: estudos de teoria política. São Paulo: Loyola, 2002a.

HABERMAS, Jürgen. $O$ discurso filosófico da modernidade: doze lições. São Paulo: Martins Fontes, 2002b.

HONNETH, Axel. Luta por reconhecimento: a gramática moral dos conflitos sociais. São Paulo: Editora 34, 2003.

HONNETH, Axel. Sofrimento de indeterminação: uma reatualização da "fílosofia do direito" de Hegel. São Paulo: Editora Esfera Pública, 2007a.

HONNETH, Axel. Reificación: un estudio en la teoría del reconocimiento. Buenos Aires: Katz, $2007 \mathrm{~b}$.

HUNT, Lynn. A invenção dos direitos humanos: uma história. São Paulo: Companhia das Letras, 2009.

LEAL, Victor Nunes. Coronelismo, enxada e voto: o município e o regime representativo no Brasil. São Paulo: Companhia das Letras, 2012.

MBEMBE, Achille. Crítica da razão negra. Lisboa: Antígona, 2014a.

MBEMBE, Achille. Sair da grande noite: ensaio sobre a África descolonizada. Lisboa, Edições Mulemba, 2014b.

MEMMI, Albert. Retrato do colonizado precedido pelo retrato do colonizador. Rio de Janeiro: Civilização Brasileira, 1967.

NASCIMENTO, Abdias. O genocídio do negro brasileiro: processo de um racismo mascarado. São Paulo: Perspectivas, 2016.

RANCIÈRE, Jacques. O ódio à democracia. São Paulo: Boitempo, 2014.

RAWLS, John. Uma teoria da justiça. São Paulo: Martins Fontes, 2000a.

RAWLS, John. O liberalismo politico. São Paulo: Ática, 2000 b.

RAWLS, John. Justiça e democracia. São Paulo: Martins Fontes, 2000c.

RAWLS, John. Justiça e democracia. São Paulo: Martins Fontes, 2003.

SOUZA, Jessé. A construção social da subcidadania: para uma sociologia política da modernidade periférica. Belo Horizonte: Editora da UFMG, 2012. 